\title{
New species of prunoid radiolarians from the Antarctic Neogene
}

\author{
DAVID LAZARUS ${ }^{1}$, KAROLINE FAUST ${ }^{2} \&$ IRINA POPOVA-GOLL $^{3}$ \\ ${ }^{1}$ Museum für Naturkunde, HU, Invalidenstrasse 43, 10115 Berlin, Germany (e-mail: david.lazarus@rz.hu-berlin.de) \\ ${ }^{2}$ Rummelsburgerstrasse 37, Berlin, Germany \\ ${ }^{3} 1418$ Clement Court, College Station, TX 77840, USA
}

\begin{abstract}
Radiolarians with 'prunoid' morphologies (here defined as spumellarians with distinct external, generally ellipsoidal shells, usually bearing a pylome and having a lithelid, pylonid or spongy internal structure) are very common in polar Neogene sediments. Use of these taxa would improve resolution in Antarctic Neogene biostratigraphic and palaeoceanographic studies significantly, but the taxonomy of prunoids is poorly known. This paper reviews the existing literature of generic names commonly used for prunoids, mostly dating from the nineteenth century. With the exception of Larcopyle Dreyer 1889, these names are either assigned to other, non-prunoid groups or are considered to be nomina dubia. Fourteen species, subspecies or varieties - most of them new - of Larcopyle from Antarctic Neogene sediments are described, illustrated with full plates and stratigraphic range data are provided: L. augusti n. sp., L. buetschlii Dreyer, 1889, L. eccentricum n. sp., L. hayesi Chen, 1975 hayesi n. variety, L. h. irregularis n. variety, L. labryinthusa n. sp., L. nebulum n. sp., L. peregrinator $\mathrm{n}$. sp., L. polyacantha (Campbell \& Clark 1944) n. comb. polyacantha n. subsp., L. p. titan n. subsp., L. p. amplissima n. subsp., L. titan (Campbell \& Clark, 1944) n. comb., L. pylomaticus (Riedel, 1958) n. comb. and L. weddellium $\mathrm{n}$. sp. J. Micropalaeontol. 24(2): 97-121, October 2005.
\end{abstract}

KEYWORDS: Southern Ocean, plankton, taxonomy, stratigraphy, Miocene

\section{INTRODUCTION}

Antarctic Neogene radiolarian faunas hold a wealth of information that can be used in studies of stratigraphy, evolution and palaeoceanography. These faunas are generally exceptionally well preserved, moderately diverse, and are found in virtually all sediments from the Antarctic region of Neogene age. Their potential, however, has yet to be fully exploited, in part due to the still highly incomplete nature of their taxonomy, even at the most basic level of species descriptions. The majority of wellpreserved taxa found in these sediments have probably not yet been described, and much nomenclatural confusion surrounds many of those that have been.

Antarctic, and polar radiolarian faunas in general, differ from those of lower latitudes in the relative abundance of many family-level groups. The spumellarian families Spongodiscidae Haeckel, 1862, emend. Riedel, 1967, Litheliidae Haeckel, 1862, and Pyloniidae Haeckel, 1881, for example, are broadly defined groups of radiolarians that include numerous morphologies and species, particularly common in high-latitude environments; together, they often make up the majority of all specimens encountered. The taxonomy of these groups is still very poorly known. Spongodiscids, as the name implies, have a primary spongy disc structure, Lithelids are characterized by possessing a spiral structure to the shell, while pylonids are constructed from a set of 'girdle bands' ('larcoid' structure). Because of both difficulties in observing these complex structures, and possible intermediate forms, it has still not been established if these features represent true monophyletic groups, particularly at the family level.

All of these groups have complex morphologies which can show a great range of variation, and intergradation between different forms in this group is quite common. It is not currently known to what extent this morphological variability represents genetically based variation, nor is the genetic structure of radiolarians at the species level generally known. Developing and applying species concepts are complicated further in members of these groups by the presence of numerous incomplete specimens which lack sufficient diagnostic characters for use and (in addition) due to the difficulty of determining complex structures such as spirals within shells. These are not only partially obscured by the outer shell, but their form is also frequently difficult to determine since the (fixed) orientation of the shell is generally random on the normal radiolarian slide, and such structures can thus appear to the viewer in cross-sectional view to be a spiral, a set of concentric rings, or other, more complex shapes (see also Benson, 1966 for discussion). For these reasons, most workers have avoided using these otherwise very abundant forms in their research.

This study describes several of the more common species belonging to these groups from Antarctic Neogene sediments, particularly most of the common prunoid forms. The term 'prunoid' originates with Haeckel (1887) as Prunoidea, one of the highest level taxonomic categories within the Spumellaria. Haeckel (1887, general introduction) apparently considered the primary geometry and symmetry of the shell to reflect basic patterns of biological differentiation in the group, including growth and orientation of the living individual in the environment. Thus, he defined ellipsoidal forms (one of three spatial axes longer than the other two) as prunoids, while forms with all three axes of different lengths were classified as larcoids. While basic shell shape is also considered to be important today, modern classifications are not so rigidly hierarchical in nature. Features that today would be considered to be, at least in some instances, even more important for higher-level classification of spumellarians, such as internal shell structural topology, number and distribution of primary beams and spines, or the presence of specialized structures such as the pylome, were only of secondary importance in Haeckel's system, being used mostly at the 
level of genera and species. This basic confusion at the highest level of classification has affected much subsequent work. Dreyer (1889), for example, considered stylosphaerid and pylome-bearing 'prunoid' forms together, as this was the concept that his predecessor had provided. In this context it is, perhaps easier to understand why Dreyer would look for homologous structures - and find them - in such disparate materials.

In more recent years the term prunoid has tended to be used in a purely informal way by many workers to refer to radiolarians of a general ellipsoidal or slightly flattened ellipsoidal shape and not readily assignable to other categories (such as the stylospharids), but the term has lacked a precise definition of scope or uniform usage in practice. The term 'prunoid' radiolarians, as used in this study, is informal and refers to spumellarians with a well-developed external lattice shell, a generally ellipsoidal or slightly flattened ellipsoidal overall shape and usually (though not always) possessing a pylome - an approximately circular area, usually open, of the shell at one pole, generally surrounded by teeth or spines - and a set of irregular, spiral or pylonid internal whorls, partially also spongy. It excludes forms with well-developed sets of concentric spherical medullary shells, as well as forms lacking a distinct external shell (e.g. Lithelius nautiloides Riedel). Numerous variations exist even within this definition, such as specimens with a more or less spherical shape; further, there are clearly forms which are transitional in character to non-external shell, non-pylomebearing lithelids and pylonids, and to fully spongy spongodiscids. None the less, this definition provides a useful way to partition the otherwise overwhelming diversity of forms within these three family-level groups into a more manageable subset of forms for this current initial analysis. It should be noted that the definition here does not honour Haeckel's strictly geometric classification, specifically the distinction between Prunoidea and Larcoidea, as it is felt that these categories are artificial. Prunoid radiolarians, as defined here, have generally high abundances in Antarctic Neogene assemblages, with more than $10 \%$ of the individuals in assemblages often belonging to this group.

In recent years the Ocean Drilling Program (ODP) has recovered extensive numbers of new radiolarian-rich Neogene sections and the need for more complete descriptions of Antarctic Neogene assemblages has become more urgent. At the same time, the recent availability of efficient, inexpensive digital means for taking, archiving and comparing images of radiolarians has made studies of morphologically complex groups much easier. This study presents a first step towards a better description of Antarctic Neogene radiolarian faunas by describing many (but by no means all) of the more common taxa of prunoids and reviewing the often conflicting literature on the nomenclature of these forms.

It is beyond the scope of this present work to create new, more natural genus or family-level taxa, as this would require study of additional materials and a more detailed examination of internal shell characters than has currently been carried out. Indeed, previously defined family-level distinctions are largely abandoned in this study. A fresh start is made, beginning in this study with the lowest level of individuals and species and hoping that, from this base, in future studies it will be possible to define natural groupings (genera and families). This largely follows the approach to radiolarian taxonomy advocated by Riedel (1971) and pursued by him in revising much radiolarian taxonomy over the subsequent decades. The current goals are twofold. Primarily, it is hoped to provide a set of species-level descriptions which will allow these common taxa to be used more extensively in practical applications, such as improved Antarctic biostratigraphy, and in palaeoceanographic work. Secondly, because of the binomial system used for organisms and the consequent need to use at least one valid genus name even to define species-level taxa, the general taxonomic literature is reviewed and an attempt is made to determine which (if any) of the older generic names are applicable to these forms. The paper begins by discussing the history of prunoid taxonomy, which is followed with a description of new materials and taxa.

\section{PRIOR REPORTS OF ANTARCTIC NEOGENE PRUNOID SPECIES}

The earliest studies of Antarctic radiolarians, by Ehrenberg and Haeckel, were part of more general studies, and are dealt with later in the Discussion section. These studies, in any event, did not illustrate or describe any taxa that can be assigned confidently to the prunoid group of the present study.

Popofsky (1908) studied Antarctic spumellarians collected by the German South Polar Expedition and other cruises (Valdivia and Gauss). He discussed several lithelid taxa, but did not report, or at least illustrate, any prunoid taxa. Riedel (1958) was the next to produce a major work devoted to Antarctic radiolarians. He described one new species - Spongurus pylomaticus that is included in the materials here, but other spumellarian taxa mentioned by him cannot be assigned to the prunoid morphotype. Hays (1965) referred to four species of Prunopyle Dreyer: P. antarctica Dreyer, P. titan Campbell \& Clark, and two new species, $P$. tetrapila and $P$. buspinigerum. Three of Hays' species are forms with concentric spherical medullary shells and, thus, not within the scope of the present study. $P$. titan, however, is a typical prunoid species and is included in this analysis. Petrushevskaya (1967) provided a very detailed treatment of Antarctic radiolarian taxonomy and, in addition to recognizing several lithelid species of previous authors, she illustrated a form in open nomenclature - Spongurus sp. that is considered here. In her study of DSDP Leg 29 sediments, Petrushevskaya (1975) extended her work to include older materials and illustrated, using both previously published names and open nomenclature, several additional forms that are relevant to this study. The only new prunoid species she described - Lithocarpium monikae - is Oligocene in age and, thus, beyond the scope of this study. In both of Petrushevskaya's works, the figures and plates are unfortunately sometimes of poor quality, which makes comparison with materials in this study difficult.

Chen (1975) also published a detailed taxonomic study of Antarctic radiolarians, similar in scope to that of Petrushevskaya (1975), using material from DSDP Leg 28. However, as this volume was published after that of Leg 29, Petrushevskaya's (1975) names generally have priority (see also Lazarus, 1990 for discussion). Chen's new species Prunopyle hayesi is, however, considered here. Weaver (DSDP Leg 35, 1976; DSDP Leg 71, 1983) and Lazarus (ODP Leg 113, 1990; ODP Leg 120, 1992) reported no new prunoid taxa and used the nomenclature of Chen (1975) for all forms reported. 
Abelmann (ODP Leg 113, 1990) reported several new prunoid taxa in open nomenclature (Prunopyle species A-D, Tholonid sp. A and B), but no new prunoid species in her Leg 120 report (1992). Caulet (Leg 119, 1991) described no new prunoid taxa, but used a mixture of nomenclatural terms from Chen (1975) and Petrushevskaya (1975), as well as new combinations in his report.

Studies of living Antarctic radiolarians are rare and only Abelmann (1992) reported taxa of prunoid morphology, including Spongurus sp., S. pylomaticus Riedel and Larcopyle buetschlii Dreyer, a form originally described from the North Pacific that is included in the current study.

These relatively few species descriptions, several of which are in open nomenclature only, are the starting point for this work.

\section{PRIOR TAXONOMY OF PRUNOIDS}

The above studies have relied, particularly for generic concepts, on prior studies of prunoid forms from other geographical regions. Much of the current confusion in radiolarian taxonomy in general relates to the often unclear generic and species concepts of earlier workers, and this problem is present in prunoid taxonomy as well. Thus, early worker's taxonomic concepts in this group are reviewed, in chronological order.

\section{Ehrenberg}

Ehrenberg (1795-1876) was the first worker to publish extensively on radiolarians and one of the very few early workers to document his work carefully, not only with drawings, descriptions and publications, but also with original materials, which today are stored at the Natural History Museum in Berlin (Lazarus, 1998; Lazarus \& Jahn, 1998). Unfortunately, there do not appear to be any prunoids in the published taxonomic work of Ehrenberg.

Pylosphaera Ehrenberg, 1859 (p. 12) is the only name that might be a prunoid, but Ehrenberg's drawing sheet (Ec no. 1568 - apparently never published; micas in Case 32 tray 8 according to Clara's index) shows what seems to be a theoperid, or a part of one - not even a spumellarian, in other words. The drawing is, confusingly, stored in a genus label (a paper fold) in the drawing collection with Pterocodon and Rhopalastrum.

Looking at the plates in Ehrenberg's Mikrogeologie (1854), the following taxa and probable modern concepts are seen, all on his plate 19. The numbers below refer to the individual figures in the plate.

48, 49 - Haliomma ovatum 1844 - ellipsoids of unknown type, no spines, pylome or internal structures visible

51 - Haliomma Aequorea 1844 - a pylonid, e.g. Tetrapyle or similar

61 - Flustrella spiralis 1844 - unidentifiable, fragmentary specimen, possibly a Lithelius minor or similar lithelid, but not a prunoid

62 - Flustrella concentrica - as above, though it could also be a stylodictyid.

No other plates contain obvious prunoids.

\section{Haeckel, 1862}

Haeckel, in his 1862 monograph discusses lithelids and pylonids only briefly and makes no mention of, and gives no illustrations of prunoids.

\section{Stöhr, 1880}

This appears to be the oldest work mentioning forms where the illustrations and text have been interpreted previously as referring to this group. It is thus essential to consider Stöhr's taxonomic concepts carefully, as to the extent that they can be identified unambiguously, they have priority in the code of Zoological Nomenclature. Stöhr's taxonomic names have also been used by several modern workers, including Petrushevskaya (1975) and Caulet (1991).

Stöhr worked in Munich, where he was head of the Bavarian State Mining Service. His paper (Stöhr, 1880), unfortunately, provides no detailed locality information, defines no types and gives no indication of where the studied material might now be stored. The Paleontological Museum in Munich was unable to locate any material from him, either in their own collections, or those of the state geological survey (H. Mayr, pers. comm., 2002).

Stöhr's illustrations can be assigned mostly to existing, nonprunoid taxa, but his new genus Ommatodiscus at first glance at least appears to be a prunoid and is supported by several illustrations and extensive descriptions. Stöhr based a new family - the Ommatodiscida - on this genus. The full definition of both the family and of $O$. haeckeli are given here in translation (no definition was given separately for the genus):

Ommatodiscida

Over both sides of a round, elliptical or egg shaped median plate, that is formed from concentrically arranged septa, and which are cut by radial beams, symmetrically formed, more or less high, spongy cellular structures are built, so that the entire form is spherical, ellipsoidal, or lens shaped. The entire structure is overlain by two porous cover plates, usually possessing small spines, and which are connected to the underlying uneven surface of the cellular [shell] body. The radial beams of the median plate extend beyond the shell periphery as small teeth. Below on the narrower side of the shell is an opening surrounded by teeth. Frequently there is a small latticed sphere in the centre of the median plate.

Ommatodiscus - Stöhr, 1880, type species O. haeckeli Frizzell \& Middour, 1951

Ommatodiscus haeckeli (Tripoli Fm., Sicily) [p. 115], Pl. 6, figs $7,7 \mathrm{a}$

Circular-ellipsoid form: The median plate is made of 5 elliptical, concentric septa, that are separated from each other by a distance equal to the diameter of the innermost ellipse. They are cut by the radial beams in a way that the chambers thus formed are slightly less broad than tall; the extended radial beams appear on the periphery as short teeth. The cellular sponge is built up from the median plate in such a way, that an ellipsoid is formed, that appears to be only slightly lower than the breadth of the median plate. The opening, surrounded with teeth, is $1 / 3$ the width of the shell. The holes of the cover plate are small and irregularly arranged, and always lie on small peaks, as is shown in Figure 7a: there distance from each other is 2-3 times as broad as the holes themselves. In the middle of the median plate there appears to be a small latticed sphere, although even with higher magnification one can not be certain of this. 
The four Ommatodiscus species described by Stöhr ( $O$. haeckeli, $O$. decipiens, $O$. laevigatus and $O$. fragilis) differ only in the number of concentric septa (from 3-7) and, in one species $O$. fragilis, in that the gap between outermost and first inner septa is larger than the rest.

The illustrations, however, are too abstract to be sure of species identification alone, although, together with the text, a fairly clear idea can be obtained of his taxonomic concepts. In general Stöhr's drawings appear to be similar to prunoids with numerous tight, regular whorls with large aligned pores - e.g. forms similar to those described by Chen (1975) as ' $P$. hayesi' and similar forms, a structure that Petrushevskaya (1975) called 'pseudoaulophacid'. However, in detail, Stöhr's taxonomic concepts appear to be noticeably different than any of the material the current authors have seen in the Antarctic. In particular, he shows a distinct outer shell with fine pores for all of his Ommatodiscus species. This, clearly, is not a characteristic of the Antarctic $P$. hayesi and related forms, whose outer shell is not differentiated from the inner shells, instead possessing very large external pores corresponding to the outermost lattice wall of the internal whorls. It is possible that Stöhr was not looking at 'pseudoaulophacid'-type inner shell structures at all, in which case his description of the outer shell wall would be compatible with several well-known prunoid taxa, e.g. forms such as Larcopyle, etc. If so, it would imply that the description of the internal structures is unreliable. Furthermore, although as yet no material from Stöhr has been located, examination of the available literature for Mediterranean Pliocene-Recent radiolarians, as well for North Atlantic assemblages, shows no illustrated or cited specimens that are similar in morphology to Antarctic material of the P. hayesi 'pseudoaulophacid' type. All illustrated specimens have either a much less regular internal spongy structure and are most similar to forms often illustrated from the North Pacific as L. buetschli or, as in Leg 81, similar to forms labelled Larcopyle group and Pylospira group (Westberg-Smith \& Riedel, 1985, pl. 3, figs 3a-b, 6a-b); or, they have a distinct set of concentric, ellipsoidal medullary shells and, thus, do not conform to the typical spiral structured taxa seen in the Antarctic.

Stöhr introduced a second prunoid genus: Lithocarpium Stöhr 1880, emend. Petrushevskaya 1975 (p. 572). Type species L. pyriforme. From Stöhr's original description (just a single sentence) and figure of L. pyriforme (the only species he assigned to this genus), it appears to mean a single ellipsoidal shell with a 'tube-like' pylome, which terminates in teeth. L. pyriforme has no outer fine-pored shell but, instead, a net-like external mesh of thin bars ('Leistchen') which forms 'rather regular, rounded quadratic openings'. This description does not correspond with any of the Antarctic material seen in this study.

Stöhr notes that he looked at material from the same Pliocene Tripoli Formation, although not from the same region, as studied previously by Ehrenberg, who looked at Mediterranean radiolarians from the Tripoli Formation at Caltanisetta, Sicily (pl. XXII in the Mikrogeologie). Ehrenberg refers to this as Pliocene, although Caulet (unpubl. data, 1996) gives 'Cretaceous/Miocene' as possible ages. Ehrenberg's material might thus be useful to help determine the type of material seen by Stöhr. There are no obvious prunoids in Ehrenberg's Mikrogeologie plate. The original sample consists of a small amount of rock as well as the prepared micas. Many of the micas are loose or broken, most probably from handling by more recent workers before the micas were stored in their current tray-based cabinet system. Ehrenberg's micas have been examined (Pl. 1), but this study has only been able to locate forms similar to those described above from other, more recent Mediterranean/North Atlantic studies of Pliocene-Recent radiolarians. None of these forms appears to match well either the illustrations or text descriptions given by Stöhr for Ommatodiscus or Lithocarpium: the specimens seen in the Caltanisetta material ( $\mathrm{Pl}$. 1) differ in many respects, such as having irregular or spiral inner structures and do not possess anything that might be interpreted as a 'median plate'. The pylomes, if present, are not nearly as well developed as indicated by Stöhr.

Lastly, Dreyer (1890), in his own later study of Caltanisetta material, and in his 1889 work, clearly considered Ommatodiscus to be, not a prunoid in the sense of this paper, but a porodiscid, i.e. a flat pylome-bearing disc with variously developed concentric and radial partitions. In this interpretation he agreed with that of Haeckel (see also below) and this interpretation was also followed by Campbell (1954). The current authors think this interpretation is, indeed, possible, as it would explain several otherwise difficult to understand features of Stöhr's original description - particularly the numerous small external pores and the discoid overall shape.

From the above, it is concluded that, until it is possible to examine either Stöhr's original material, or to collect new material from precisely the same (currently unknown) locality, it is not possible to assign confidently Ommatodiscus or Lithocarpium to any of the Antarctic material in this study. Indeed, the concept of both these genera as given by Stöhr is too much at variance, not only with the Antarctic material, but also with the modern literature on late Neogene MediterraneanNorth Atlantic radiolarians, to be used with any confidence. They should be considered nomina dubia, and not used in modern practice.

\section{Haeckel, 1887 (Challenger Monograph)}

Haeckel divided all Spumellarians into four high-level groups based on overall symmetry of shell shape. Thus, Prunoids were divided from Larcoids based on the latter having all three primary axes of the shell with different dimensions. Rigid application of this rule frequently created artificial duplication of genera and even species, since this geometric criterion, while useful, can often vary within lower-level taxa such as genera or even species. Many of his other higher-level criteria - number of shells, etc. -are also now known to be often unreliable: shell number in actinommids for example varies with ontogenetic development (e.g. Bjørklund, 1977; see also more general discussion and citations to critiques of Haeckel's taxonomy in De Wever et al. 2002). Lastly, Haeckel tended to see more regular structure in the internal shells of 'prunoids' than perhaps was really there. He certainly saw larcoid (girdle-band) structures much more commonly than most subsequent authors. It is possible that some of his illustrated taxa with girdle-band internal structures are prunoids with the more typical spirals or irregular whorls, but this cannot be determined in the general absence of type specimens that characterizes Haeckel's work. 

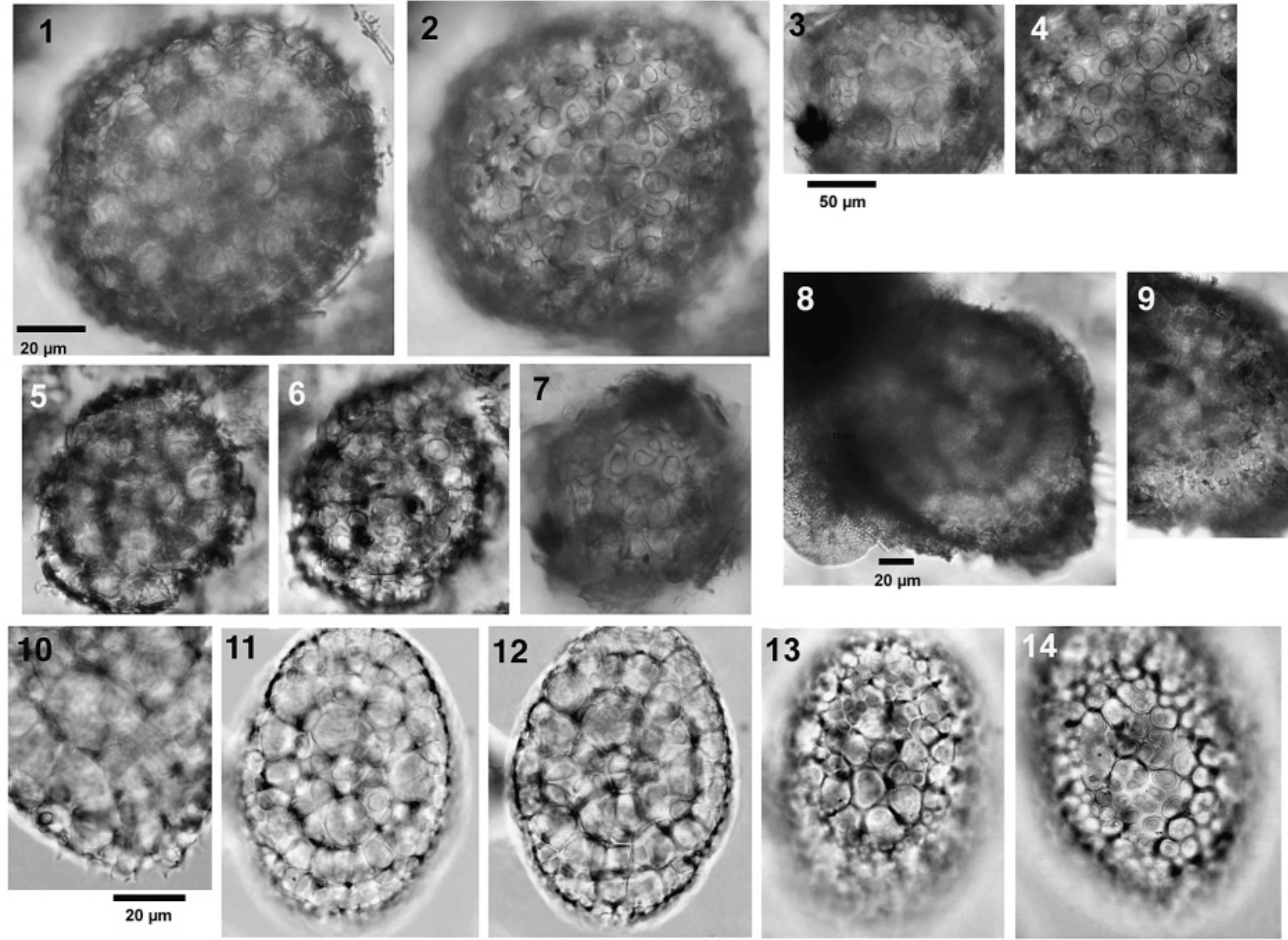

Explanation of Plate 1.

figs 1-9. Caltasinetta radiolarians, Ehrenberg Collection, Berlin, Sample no. 1882, micas in Case 28, Tray 6: 1, 2, specimen 1 (strip 1, mica 3), focused respectively on internal structures and outer shell surface; 3, 4, specimen 2 (strip 1, mica 3); 5, 6, specimen 4 (strip 3 , mica 4); 7, specimen 5 (strip 3, mica 4); 8, 9, specimen 3 (strip 3, mica 4), note polar spines, spiral whorls, large gap between whorls and outer shell in fig. 8. figs 10-14. Larcopyle buetschlii ? from tropical Pacific Challenger Station 271 sediment, Haeckel Teaching Slide Collection, Museum für Naturkunde, Berlin: figs 10-13, same specimen at different focal depths; 14, second specimen, focus on outer shell. Scale bar for figs 1, 2, 11-14 with fig. 1; for figs 3-7 with fig. 3; for figs 8, 9 with fig. 8; for fig. 10 with 10.

Looking at Haeckel's plates, there are just a couple of illustrations possibly equivalent to the concept of prunoids used in this study. Regardless of how Haeckel conceived these taxa, they are potentially still valid species and thus would have precedence over anything defined by Dreyer (below), if identifiable as prunoids in the current study's sense of the term. These taxa are:

Discopyle osculata and D. elliptica (both n. sp.), plate 48, p. 573.

?Stomatodiscus osculatus n. sp., plate 48, p. 503.

Discopyle is described as having a 'Triopyle'-type central shell - this, in the definition of Triopyle (p. 565) and as illustrated in plate 48 , is a hexapyle type pylonid. Close examination of Haeckel's illustrations of D. osculata and D. elliptica shows that, although the outer shell is very clearly prunoid, the inner shell in both is sketched as a hexapyle larcoid structure. This character, together with an overall disc shape (not ellipsoid) are the defining characters for Haeckel's Pylodiscida family, in which he places Discopyle and Triopyle. Thus, neither of these Discopyle taxa, at least as defined and illustrated, can be thought of as belonging to the prunoids of the current study.
Stomatodiscus is defined by Haeckel as being similar to Stöhr's Ommatodiscus but with two oscula (pylomes), not one, as the illustration of $S$. osculatus shows. The current authors have not seen any material with two pylomes and, thus, do not consider that Stomatodiscus lies within the range of the material studied in this paper.

Although Haeckel does not provide any illustrations, he does recognize Stöhr's Ommatodiscus and family Ommatodiscida (which he places within the porodiscids, based on a flattened disc shape), noting that the internal structure of taxa in this family is 'commonly more or less obscure, as the lenticular disk is much thickened, sometimes nearly ellipsoidal'. He also notes the possible affinity of this group to the lithelids, although 'there is no indication of an internal trizonal medullary shell'. Haeckel lists Stöhr's $O$. decipiens, $O$. haeckelii, $O$. laevigatus and $O$. fragilis, and describes two new species - $O$. stöhrii and $O$. circularis from the North and South Pacific, respectively. The descriptions of these latter new species are unclear and lack illustrations. Re-examination of the original Challenger material might (or might not) make the taxa meanings clear. Of Stöhr's species, all but one are given by Haeckel as only fossil material from Sicily; however, O. fragilis is reported by 
Haeckel as living and he gives Atlantic and Pacific Challenger locations.

Larnacantha - Haeckel, 1887 (p. 621), central Pacific. The three species illustrated by Haeckel are rather unusual-looking larcoids, with prominent external spines located at the approximate corners of a cubic symmetry. There is no indication of a pylome either and so this genus is not considered a prunoid.

\section{Dreyer, 1889}

Dreyer (1889) seems to be the first worker after Haeckel to explicitly study the 'prunoid'-type taxa of this study, specifically considering forms with pylomes.

Dreyer used Haeckel's artificial shell symmetry classification which assigned not only prunoids but many other groups into artificially duplicated subfamilies, genera etc. For example, Dreyer considered some stylosphaerid species to be related closely to some species of prunoids. Dreyer's idea of a pylome was essentially any unusually large pore in the outer shell, and almost certainly included characters that are not homologous he saw pylomes in taxa which today would be classified as collosphaerids, stylosphaerids, as well as prunoids, as the latter term is used in this study. Specifically, he considered the large pore seen at the base of some polar spines of stylosphaerids to be pylomes. Dreyer explicitly defined a number of new genera and species, as well as using those concepts reported earlier by Stöhr and Haeckel. He also made use of deep-sea sediments and plankton samples from the Challenger expedition, which makes it much easier to find modern materials for comparative purposes. Dreyer gave a very detailed description of his taxa, as well as excellent, if somewhat idealized, illustrations. His generic concepts are reviewed here.

Prunopyle Dreyer, 1889, type species $P$. pyriformis, type locality - ?, emended by Kozlova \& Gorbovetz, 1966 (p. 66). Dreyer's drawing of $P$. pyriformis, and text description, suggest strongly that it is a stylosphaerid, not a prunoid, as the illustration and text clearly indicate the presence of polar spines. He specifically notes that the 'pylome' in this form, and all other forms assigned by him to the genus Prunopyle, is very similar to the pores seen at the base of polar spines in other stylosphaerids. Prunopyle is placed in the grouping 'Entwicklung eines Pyloms aus einem Radialstachel' ('development of a pylome from a radial spine'; p. 129), and he comments specifically on P. pyriformis: 'This form is already typically pylomatic, is however very closely related to the previous [taxon illustrated, Xiphatractus umbilicatus, an indisputable, if rather dissolved-looking, stylosphaerid specimen - note by present authors], and the pylome clearly shows its origin from a polar spine' (p. 130). Prunopyle is thus either an invalid concept or, if valid, a member of Stylosphaeridae and not usable for the current concept of prunoid materials. This interpretation was also briefly given previously by Petrushevskaya (1975).

Sphaeropyle Dreyer, 1889 (p. 88). Type species S. langii. For forms with concentric, spherical medullary shells. Not included in the present study.

Larcopyle Dreyer, 1889, type species L. buetschlii. Larcoid radiolarians with a single pylome on the main shell axis.

\section{Larcopyle buetschlii Dreyer, 1889}

1889 Larcopyle Bütschli Dreyer: 124, pl. 5, fig. 70.

1966 Larcopyle Bütschli Dreyer: Benson; 280, pl. 19, figs 3-5.

1984 Larcopyle buetschlii Dreyer: Nigrini \& Lombari; pl. 13, fig. $1 \mathrm{a}, \mathrm{b}$

[Note: Abelmann (1990) used L. buetschlii for forms in her Antarctic Neogene material. The form shown by her is not the same as the North Pacific species illustrated as L. buetschlii by Nigrini \& Lombari (1984).]

The text of the original description for L. buetschlii is given here in translation (from Dreyer, 1889):

Larcopyle Bütschli, nov. spec. Fig. 70.

The complete outline of the lens-shaped, flattened shell is oval, in which, although not very significantly, the oral pole is wider than the aboral. In the centre of the skeleton there is clearly visible a 'trigonale', Larnacilla shaped medullary shell, while the shell is enclosed externally by a unified shell mantle. This has a smooth surface and small irregular polygona to round meshes of unequal sizes which are approximately twice the breadth of the beams, sometimes also wider. Between the Larnacilla shaped medullary shell and the outer shell mantle there is a construction of opaline beams, whose form indicates a close affinity to the lithelids and phorticids (for details see illustration). The beams of this inner construction are thicker than those of the shell mantle. The pylome is relatively small, about as broad as the medullary shell, and is framed by small teeth. The opaline beams of this form are thin and give the entire shell a very soft, transparent impression, and thus the finer structure and layout of the opaline beams is rather difficult to recognize.

Diameter of the shell: 0.137: 0.194 [all measurements in millimetres - Dreyer (1889, p. 11)]

Diameter of the pylome: 0.036

Diameter of the pores of the outer shell mantle: 0.004-0.007 Thickness the beams of the outer shell mantle: $0.002-0.004$ Thickness of the beams of the inner construction: 0.004 0.007

Length of the pylome spines: up to 0.025

Basal width of the pylome spines: 0.004

Station 232, bottom; 266, surface, 271, bottom

As these pylome bearing larcoids cannot with certainty be assigned to described larcoid families, I have created a new family for them, which to the previous nine families can be added as the tenth. All not yet discovered pylome bearing larcoids would most simply best be assigned to this family, regardless if they have other shell features that connect them to one of the known nine families.

Fig. 70. Larcopyle Bütschli, nov. spec., nov. gen. 435X enlargement.

In order to clearly illustrate this very complicated form, almost all of the upper (except for a small piece to the right of the pylome), and the middle part of the lower, outer fine-meshed shell mantle has been shown broken away. Similarly, part of the upper, inner coarse spiral beam structure has been removed, to show the central larnacilla shaped medullary shell. 
Type locality. Not given uniquely. Dreyer referred to three different Challenger locations as the source of his material, but does not indicate the material used for his illustrated specimen. No information is given as to the deposit of a type specimen.

Discussion. Of all the older genus concepts reviewed here, Larcopyle seems to be the best described/illustrated and, most importantly, is the only concept whose type series materials can be still examined, although no explicit type or even single type locality was designated. However, Dreyer's description emphasizes several aspects of the shell which make it uncertain if the forms illustrated by Benson (1966), Nigrini \& Lombari (1984) and many subsequent workers are really the species described by Dreyer. Dreyer, in particular, noted that his form had a flattened, lens-shaped shell, a smooth outer surface and a quite large distance between the outer shell and outermost inner whorls. These features are not characteristic of the form currently called $L$. buetschlii. In an attempt to resolve this, Haeckel's teaching set of plankton and sediment slides was examined, one set of which is held in the Berlin Museum für Naturkunde and which includes two strewn slides of radiolarians from sediment from Challenger station 271. Two complete specimens, which are felt to be either very similar, or conspecific, to modern usage of $L$. buetschlii, were found (Pl. 2). No specimens were found, however, that matched Dreyer's description and illustration fully. Some of the specimens illustrated by Benson (1966) from the Gulf of California seem to match Dreyer's illustration more closely, but the internal structures are not clear enough in his photographs to be sure. Nigrini \& Lombari (1984) noted that there are actually two forms commonly included in recent $L$. buetschlii, the common small form which they illustrated, and which has been referred to above and a rarer large form. This latter may be the form illustrated by Dreyer and Benson.

\section{Modern (post-WWII) research}

Campbell \& Clark (1944) described two prunoid taxa from California sections - Prunopyle titan and Larnacantha polyacantha. The assignment of taxa to genera is at variance with the current concepts, as at that time they had only Haeckel's artificial higher-level taxonomy available. To create their illustrations, Campbell \& Clark (1944) used a rather unusual method, involving a suspended petrographic microscope, an automobile light bulb and projection of the image onto sheets of photographic paper mounted several metres away from the specimen (Clark \& Campbell, 1942, p. 91). The published results are less than ideal, with many of the finer details, particularly the internal structures, being unclear. These descriptions are, however, of importance because they are essentially the first modern descriptions of prunoid radiolarians, for which curated type series material is still available. This material was examined by the senior author and both species are re-illustrated in the taxonomic section below.

Riedel $(1967,1971)$ provided a much more natural higherlevel classification for radiolarians, which made the artificial, duplicative nature of many radiolarian genera clear. Although this work provides the basis for the current revisions in this study, Riedel did not himself provide any detailed revision of the higher-level prunoid concepts. He mentions only Lithelidae and Pylonidae and gives no new definitions of these beyond those of Haeckel.

Dumitrica, in a series of papers summarized in De Wever et al. (2002), described numerous pylonids - i.e. forms with girdles and gates - which are not part of the current study. It should be noted that in his work, Dumitrica - as Haeckel and Dreyer before him - has detected pylonid (gated) structures in groups of radiolarians that would be considered here as prunoids. In some of these forms the structures, as illustrated in De Wever et al. (2002), are ambiguous and not clearly of pylonid type. As Benson (1966) noted in an extensive discussion of this problem, first, the structures seen in these forms depend strongly on orientation of the shell and, secondly, there may be substantial variation in these characters even at fairly low taxonomic levels. This latter point is very important, since there is, to the authors' knowledge, as yet no well-established reason to believe a priori that central shell structures in Spumellaria are any more stable, or useful for higher-level taxonomic division, than any other shell character. While it is believed that a more detailed study of the central structures of the species considered in this paper would be of great value, until further evidence is available, this study does not wish to adopt central shell characters as the primary basis of the current genus-level taxonomy.

\section{A NEW BEGINNING FOR PRUNOID TAXONOMY}

There are several basic points that need to be considered in deciding how best to proceed with the use of generic names in prunoids.

1. As noted above, earlier workers based generic concepts on what are invalid family-level criteria - the degree of axial symmetry of the overall shape of the shell (spherical, ellipsoidal, flattened ellipse, etc.), or the use of nonhomologous characters, as in Dreyer's original, far too broad, definition of a pylome. This, alone, has created many needless duplications of generic names.

2. As is also clear from the above discussion of prior work, virtually all previously described genera are based on inadequately documented materials - either the descriptions are vague or the drawings are abstract; and, in nearly all cases, neither the original type series material is available, nor is a precise locality given which would allow new material to be collected. Frequently, all these problems exist for a single genus name. In the absence of any recoverable type series material, it will be impossible in most cases to ever precisely resolve the meaning of these older generic names.

3. Despite problem two above, the large majority of generic names currently used for prunoids do not appear to be prunoids, in the sense of this paper, when the original descriptions are re-examined.

4. Any major revision of this group should take into account the sometimes close morphological affinities not only to pylonids, but also to other groups, including in particular the lithelids.

5. Although not agreeing with Dumitrica's (in De Wever et al. 2002) (re)assignment of many prunoid morphotypes to the pylonids, it is acknowledged that the internal structure of the shells may also be of generic-, or even higher-level 

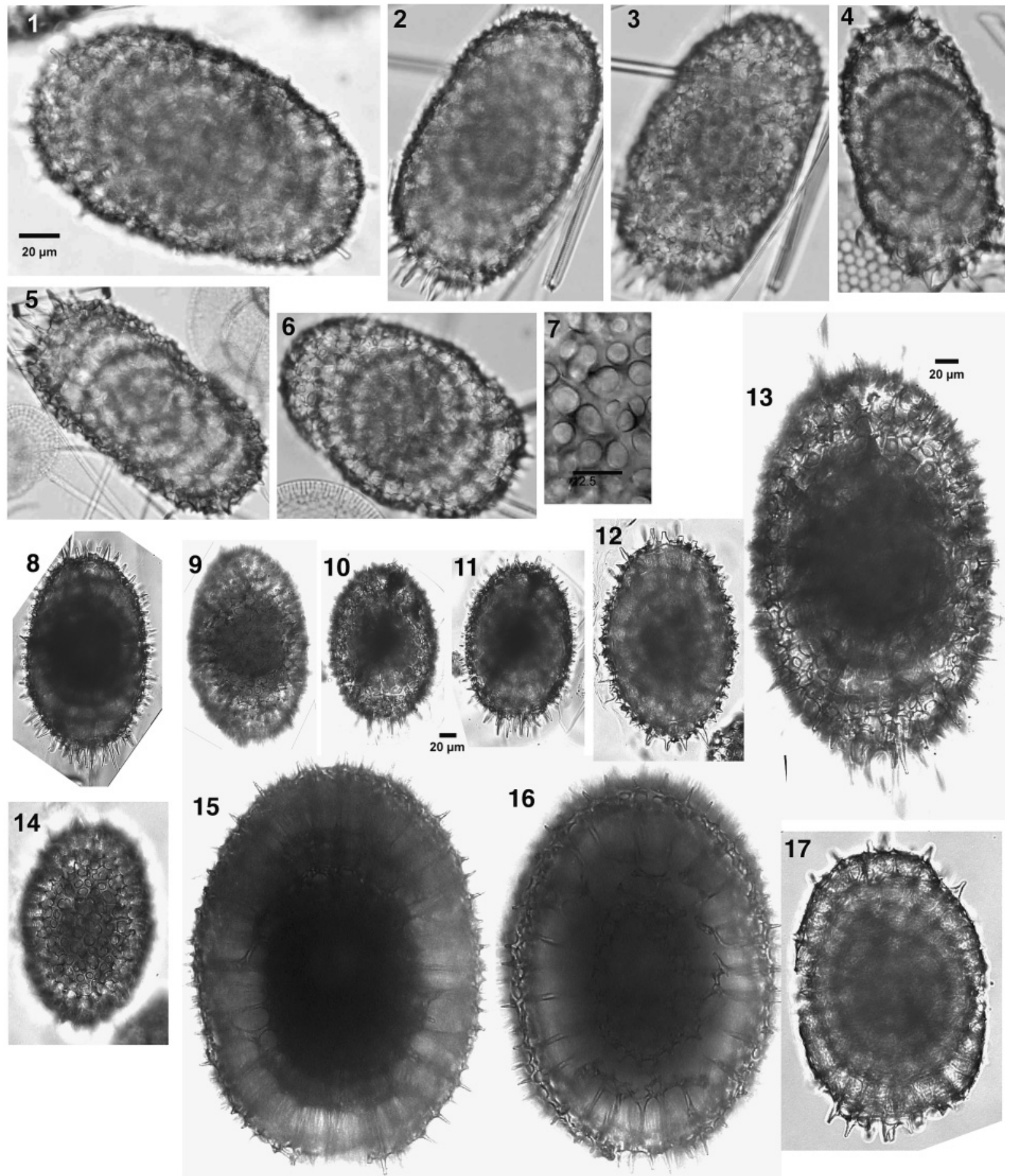

Explanation of Plate 2.

figs 1-7. Larcopyle polyacantha group, Antarctic Neogene: 1, 689B-3H-2,57 (Early Pliocene, Weddell Sea); 2, 751A-9-5,98 (Late Miocene, Kerguelen, focus on the spiral); 3, same specimen, focus on the surface; 4, 689B-6-1 (Middle Miocene, Weddell Sea); 5, 689B-6-1 (Middle Miocene, Weddell Sea), atypical specimen with subquadrate outline; 6, 751A-9-5,98 (Late Miocene, Kerguelen); 7, 751A-7-2,52 (Late Miocene, Kerguelen), close-up of outer pores. figs 8-13. Larcopyle polyacantha, Campbell \& Clark type series material, Museum of Paleontology, University of California, Berkeley: 8, 9, 13, Lectotype, labels A3468-35577, S38, UCMP No. 49590, same specimen as Campbell \& Clark (1944, pl. 5, fig. 6); 10, 11, A3468-35577, S38; 12, 14, A3467-35554, S17A; 15, 16, A3466-35541, S4; 17, A3460-35563, S25, Berkeley Museum No. 49588, same specimen as Campbell \& Clark (1944, pl. 5, fig. 4). Scale bar for figs 1-6 with fig. 1; for fig. 7 on 7; for figs $8-12,14$, 17 with fig. 10; for figs 13, 15, 16 with fig. 13. 


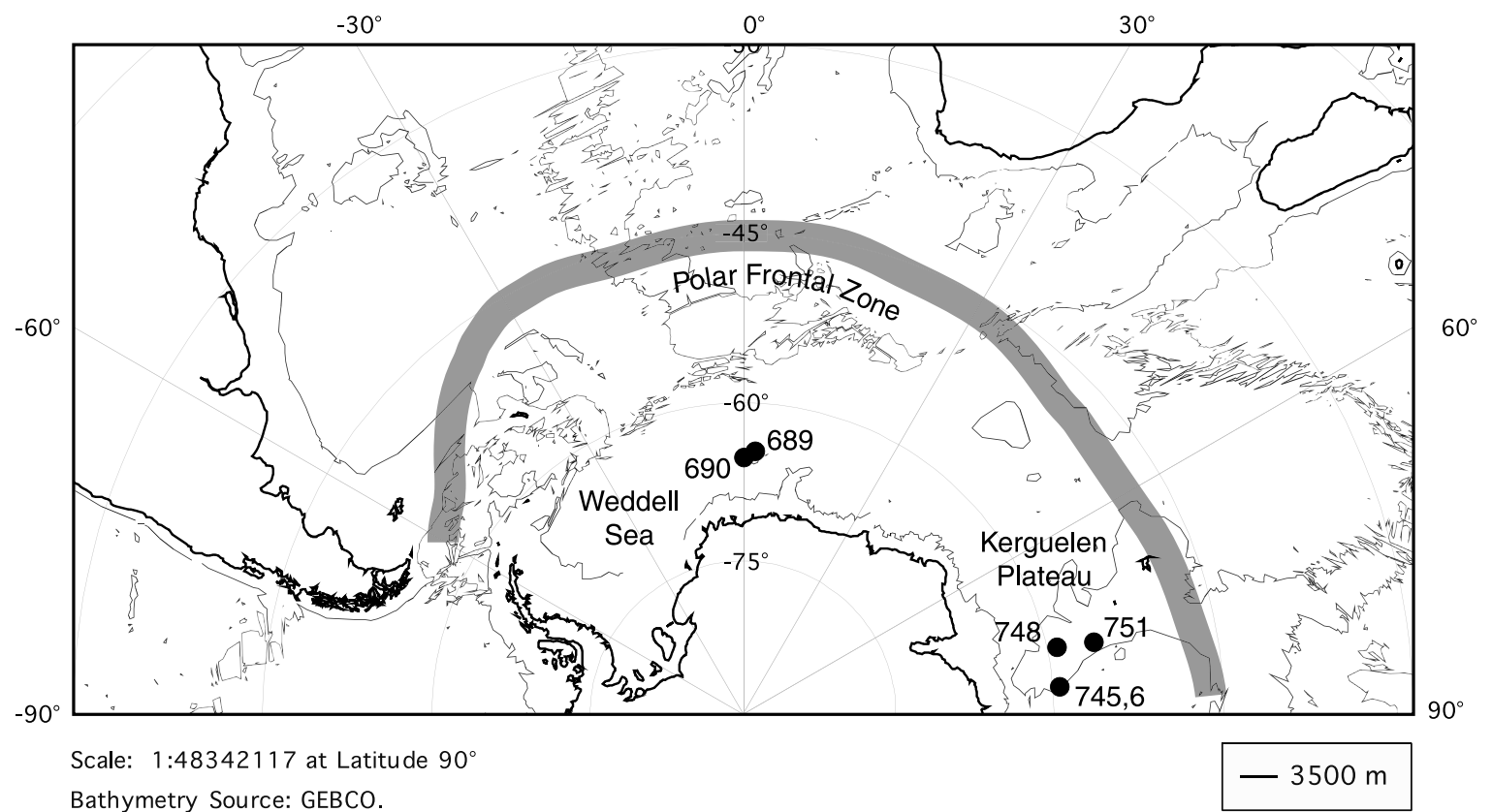

Fig. 1. Location of ODP sites used in this study. $3500 \mathrm{~m}$ isobath outlines ridge system, major basins and plateaus. Frontal zone (bounded by Subantarctic Front and Polar Front) marking northern biogeographic limit of Southern Ocean plankton shown by grey band (simplified from Orsi et al., 1995). Base map created with Panmap program (www.Pangea.de) for Mac OS.

taxonomic importance. Until such studies are carried out on materials from the current study it will be impossible to determine fully the appropriate generic names for the species-level taxa here. It would be, therefore, premature to erect new genera based solely on the characteristics of the outer, visible shells.

6. Any such major revision should include a careful evaluation of the distribution of character states using modern methods - cladistics, stratophenetics, or some combination of these. These methods have not yet been applied to this group's taxonomy. Character ranking, if used, must be based on explicit arguments and actual external data, such as biologic growth studies. Such data are not yet available for these organisms.

Thus, a fresh start seems to be required and, as a first step in re-evaluating the taxonomy of prunoids, all of the existing morphotypes in the study have been assigned to a single genus Larcopyle - which is among the better described and illustrated of the older genus names and which, if not actually anchored in a true type series of specimens, is the only morphologically relevant genus that is at least based on readily identifiable, precisely defined material (modern oceanic plankton material and deep-sea surface sediments), and including original samples from the still accessible Challenger material. Even this is problematic, in that there is as yet no designated type specimen for $L$. buetschlii, the type species of the genus and initial (modest) attempts to locate appropriate material were not successful. It must be hoped that further work with Challenger and other relevant deep-sea materials will yield specimens suitable for typification and thus provide a solid foundation for this genus.

In taking this step, it is not implied that all of the variation in morphological characteristics seen in the study material is clearly sub-generic. Forms with numerous, nearly uniformly spaced whorls and lacking a distinctly different cortical shell $(L$. hayesi, L. 'weddelium') seem to be a subgroup that is distinct from the many other forms that lack these unifying features. Further, Dreyer's concept of Larcopyle clearly was meant for forms with larcoid (pylonid) central structures. The distribution of this character, and its importance for the group's taxonomy, has not yet been determined. With sufficient additional study, as outlined above, it may be possible to subdivide Larcopyle as defined here into several new genera. Thus, the genus assignment employed in this paper will be, it is hoped, only a temporary necessity for at least some of the species included here. With additional study of this interesting group of radiolarians, a new, hopefully more natural classification will emerge.

\section{MATERIALS}

Prepared radiolarian slides for this study were drawn primarily from the senior author's collection. Most were prepared using standard techniques with $63 \mu \mathrm{m}$ sieves (Moore, 1973). Antarctic samples were originally obtained from several different Antarctic ODP drill sites recovered during ODP Legs 113, 119 and 120 (Fig. 1; Initial Report volumes). The chronologies of the sites used are well established and are based on multiple microfossil groups and magnetostratigraphy (original ODP volume stratigraphic synthesis papers; Neptune chronology database, www.chronos.org). The majority of the ages of individual samples are probably accurate to $\pm 100 \mathrm{ka}$. Exceptions include samples 689A-1-CC, 689D-4-CC and 690C-3-CC, for which no hole-specific age models are available. As no composite depth section was explicitly made for these sites, the metres below sea floor (mbsf) values for these samples were used together with the age model for the corresponding hole $(689 \mathrm{~B}$ and 690B, respectively). Depth offsets between holes of several metres are possible, which would lead to errors of $c$. $0.5 \mathrm{Ma}$. 
Sample 690B-6-2, $23 \mathrm{~cm}$ is near an inferred hiatus at the base of the same section of the core. Should this hiatus be placed incorrectly, this sample could be as much as $2 \mathrm{Ma}$ older than the value used here. These age uncertainties, however, do not in any way significantly affect the results of this study. For comparison purposes, radiolarian slides were also examined from both the tropical Pacific and North Pacific (including Sites 173, 573, and 881), and from Mediterranean sediments. The latter includes material in the Ehrenberg Collection from the Caltinasetta quarry in Sicily (Ehrenberg mica collection Case 28, folder 6; Clara Index page 118; drawings 2319-21). Although a small amount of original sediment material from Caltinasetta is available as well (Ehrenberg Collection, sample number 1882), it would not be enough to prepare an adequate radiolarian sample and, thus, it was not examined in this study.

\section{METHODS}

An initial survey of the samples was carried out to determine the range of morphological diversity in the material. This was documented with an extensive collection of video-prints, using a comparatively low-resolution consumer model printer and a simple greyscale video camera (c. 300 lines of resolution). These were sorted into preliminary groups, which were split to the lowest possible level to capture as much of the morphological variation as possible. Light micrographs and SEM images were also made at this stage to provide adequate imagery of morphological details. With this provisional taxonomy as a base, the set of samples were re-examined to trace out stratigraphic relationships. Several preliminary groupings were identified as artificial or stratigraphically inconsistent at this point and were merged. Other forms were eliminated from the analysis as it became apparent that they were more closely related to other types of lithelids beyond the primary focus of this study. At this time a new set of better quality digital images were taken, using newly available equipment: a professional quality video camera/ digitizer combination (c. 400 lines of resolution), and a 6 megapixel digital camera system (Olympus DP50). A last examination of the sample set with the final taxon concepts in hand was done to check apparent gaps in taxon distributions and to determine the taxonomic details more accurately.

\section{SYSTEMATIC PALEONTOLOGY}

The ranks and number of levels of protist classification currently vary dramatically between authors and thus are given only partially and rather arbitrarily here. A family-level assignment is not provided for this genus as the current family-level classification of radiolarians of this general type is more a hindrance than a help (see also discussion above).

\section{Class Polycystina Ehrenberg, 1838}

Order Spumellaria Ehrenberg, 1875

Genus Larcopyle (Dreyer, 1889) emend. this paper

Type species. Larcopyle buetschlii Dreyer, 1889.

Emended description. Spumellarians with a well-developed cortical shell typically of ellipsoidal or flattened ellipsoidal shape, usually bearing a pylome (an opening in the cortical shell surrounded by a peristome, teeth or spines) at one pole, and with spongy, spiral or pylonid inner shell structures, which are connected to the cortical shell either directly (e.g. as the last whorl in a spiral form) and/or by largely randomly distributed thin radial beams, which may extend beyond the surface as radial spines.

Differential diagnosis. Differs from most spumellarians (e.g. actinommids, stylosphaerids) in lacking any spherical shells; from discoid taxa (e.g. Spongodiscus, Porodiscus) in the more three-dimensional (approximately ellipsoidal) topology of both shell and internal structures, from pylonids and lithelids in possessing a well-developed cortical shell and pylome.

Remarks. This emended definition of Larcopyle is much broader than that originally given by Dreyer, but reflects the authors' conviction that most prior genus- or family-level distinctions in this broad group have been largely artificial. As indicated in the review of prior literature, it is not believed that any of the reviewed generic names previously used for such forms, other than Larcopyle, actually belong to the group; thus, these other generic names are not listed in synonymy.

\section{SYSTEMATIC DESCRIPTIONS}

In all, 13 species or subspecies of prunoid radiolarians (including one with two morphotypes) were seen in the study materials. Of these, four - Larcopyle buetschlii, Larcopyle hayesi n. comb., L. polyacantha group and L. pylomaticus n. comb. - are widely recognized forms which, in part, have been used in stratigraphic and palaeoceanographic work for several years. The remaining nine taxa have either not been described previously, or have been lumped together with other forms with which they are not conspecific. The stratigraphic distribution of the taxa is given in Table 1. A comparison of the relative abundance of taxa to each other, and versus region is also given in Figure 2.

All holotype and neotype specimens have been deposited in the micropalaeontology collections of the Natural History Museum in Berlin; lectotypes of Campbell \& Clark (1944) taxa are stored in the Paleontology Museum of the University of California, Berkeley.

\section{Larcopyle buetschlii Dreyer, 1889}

(P1. 1, figs 10-14)

See description and discussion above.

Larcopyle polyacantha (Campbell \& Clark, 1944) n. comb.

1944 Larnacantha polyacantha Campbell \& Clark: 30-31, pl. 5, figs 4-7.

1975 Lithocarpium polyacantha (Campbell \& Clark): Petrushevskaya; 572, pl. 3, figs 6-8.

1984 ?Spongurus (?) sp. B Nigrini \& Lombari: S35-6, pl. 5, figs $2 \mathrm{a}-\mathrm{d}$.

Description. The shell is sub-cylindrical to elliptical and varies in size from $150 \mu \mathrm{m}$ to $250 \mu \mathrm{m}$ (the original description gives the length of the shell as $180 \mu \mathrm{m})$. Most specimens have clusters of short to medium length, subparallel to weakly radial spines on 


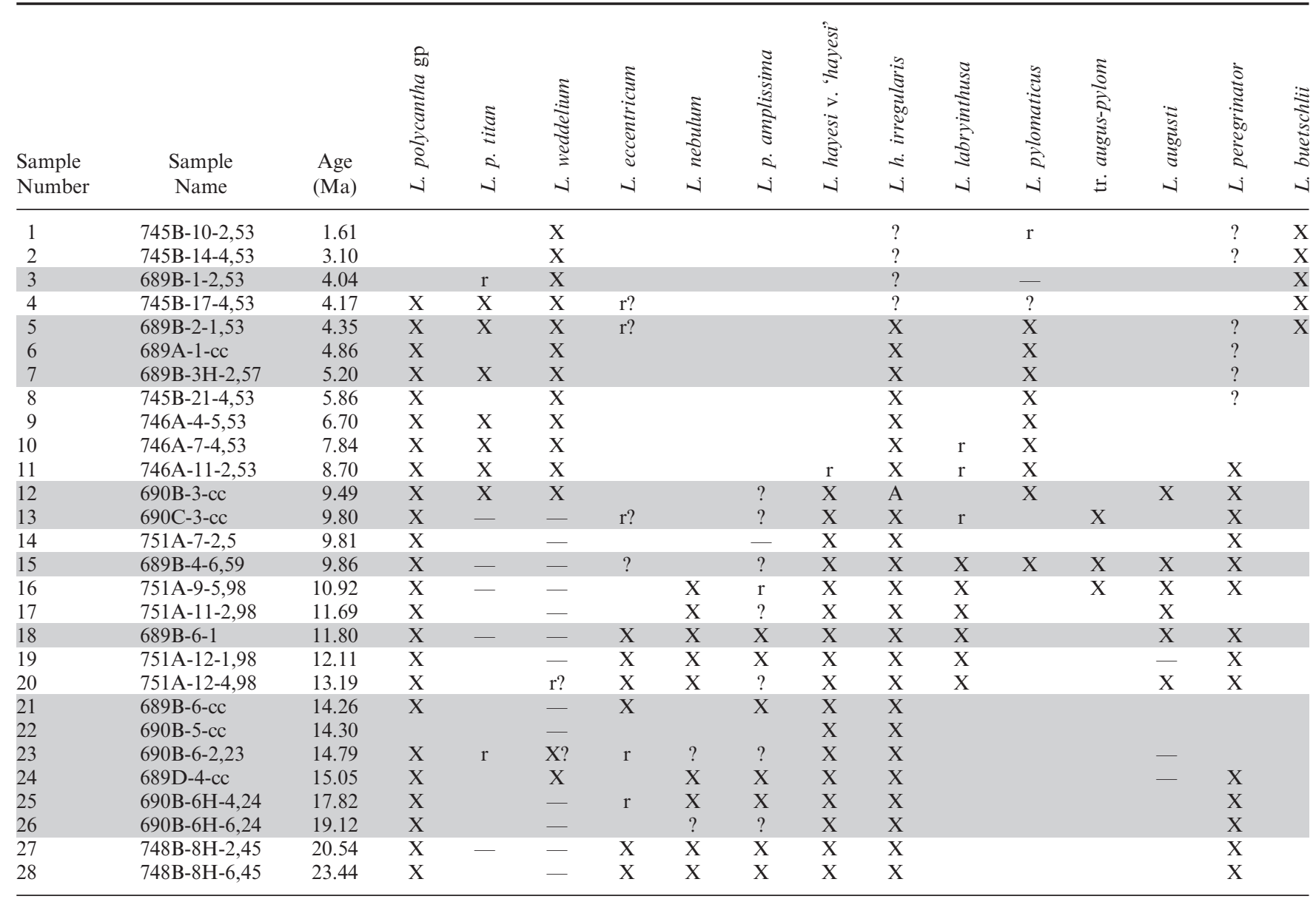

Most occurrences (X) not quantitatively estimated but are based on at least several individual specimens, exceptions are (r) - one or two specimens only, (?) - questionable identification, due either to morphological differences from typical material, or poor preservation. 'tr augus-pylom' refers to specimens morphologically intermediate between L. augusti and L. pylomaticus. Grey tinted and untinted table rows indicate Weddell Sea or Kerguelen Plateau location of samples, respectively.

Table 1. Stratigraphic distribution of taxa in Antarctic Pliocene and Miocene sediments.

one or both poles. The outer wall is perforated by small- to medium-sized, irregularly arranged pores, frames are absent in most specimens. The inner structure is made up of weakly increasing, single or double spirals, although in some specimens the internal structure is so spongy that the spirals are nearly undetectable. In some subspecies the shell shows characteristic deviations from a simple ellipsoidal shape, which is caused by the development of caps at the poles. A pylome is obvious in most specimens.

\section{Occurrence. Early Miocene-Early Pliocene.}

Remarks. Larcopyle polyacantha was first described by Campbell \& Clark (1944) from North Pacific (California coast) sediments and, to some degree, can be considered a 'garbage bag' type of taxon. The various forms in this group are related closely to each other and (as also noted by Campbell \& Clark) show a great range of morphological variation. Differences between forms are subtle and in poorly preserved individuals a precise assignment may not be possible. In this study the majority of the morphotypes that exist in this group have not been differentiated, particularly in the early Neogene. However, there is a formal division of Larcopyle polyacantha into three subspecies L. polyacantha polyacantha, L. p. titan and L. p. amplissima. It has been decided to distinguish the L. p. titan and L. $p$. amplissima morphotypes as they provide useful stratigraphic information. Larcopyle polyacantha titan, under the name Prunopyle titan, has been used extensively for biostratigraphy in late Neogene Antarctic sediments for many years. P. titan is a species that was also described originally by Campbell \& Clark (1944) from California. True P. titan morphotypes, however, are seen in Antarctic sediments only in the early Neogene, where they are generally rare. This form, in the new combination Larcopyle titan, is re-illustrated from the original type series material.

There are many different morphotypes within this group, some of which appear to be restricted to the Early or Middle Miocene in the Antarctic. There are transitional specimens between L. p. polyacantha and the other named subspecies (L. p. titan and L. p. amplissima) which occur throughout the 


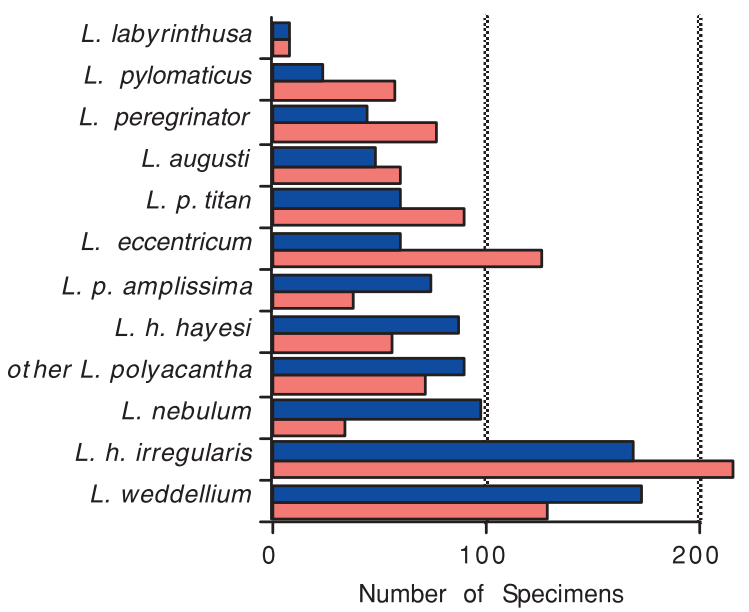

Fig. 2. Relative abundance of taxa encountered in representative samples from the Kerguelen Plateau (dark grey; blue in on-line version) and Weddell Sea (light grey; red in on-line version), ranked by abundance in Kerguelen samples. Because of the uneven distribution of samples vs. time in each region and time-restricted ranges of individual species, rankings shown are only a rough guide to overall relative abundances of taxa.

stratigraphic intervals in which these latter subspecies are found. In the early Miocene, there are gradational specimens between $L$. $p$. polyacantha and several of the other species described in this study, including L. nebulum and L. hayesi (variety irregularis). There also appear to be some regional differences: for example, specimens that correspond to Campbell \& Clark's (1944) figured specimen number 7 (pl. 7) from California have not been seen in this Antarctic material. The specimens illustrated by Nigrini \& Lombari (1984) are somewhat larger, and have a thinner cortical shell, than is typical of most of the Antarctic material studied here, but otherwise fall within the range of variability for this species group.

\section{Larcopyle polyacantha polyacantha $\mathrm{n}$. subsp.}

(P1. 2, figs 8, 9, 13)

Lectotype. Berkeley slide labelled A3468-35577, S38. UCMP No. 49590. Same specimen as Campbell \& Clark (1944, pl. 5, fig. 6).

Description. Specimens of Larcopyle polyacantha without polar caps, with a generally regular ellipsoidal shape and relatively equally spaced whorls from the centre to the outer wall of the shell.

Remarks. All of the specimens of Campbell \& Clark (1944) examined so far can be assigned to this subspecies. The type specimen for this subspecies is chosen from the original type series material of Campbell \& Clark, who did not explicitly designate a holotype specimen.

\section{Larcopyle polyacantha titan $\mathrm{n}$. subsp.}

$$
\text { (P1. 3, figs 1-12) }
$$

1975 Prunopyle titan Chen: 454, pl. 23, figs 1, 2.

1990 Prunopyle titan Chen: Lazarus; 717, pl. 5, figs 1, 3, 4.
Derivation of name. The name 'titan' is retained here to maintain the maximum degree of compatibility possible with the existing Antarctic biostratigraphic literature. It also reflects the relatively large size of this form in comparison to other morphotypes within the species group.

Holotype. Plate 3, fig. 3, sample 746A-11-2, $53 \mathrm{~cm}$. Museum für Naturkunde Mikropaläontologie, Accession Number ECO-016.

Occurrence. Late Miocene-Early Pliocene (c. 9.5-4.0 Ma). A few specimens of this morphotype were also seen in sample 690B-6-2, $23 \mathrm{~cm}$ (estimated age c. 14.8 Ma).

Description. The relatively large shell, length $170-250 \mu \mathrm{m}$, has a very characteristic ellipsoidal shape with rounded truncate conical ends (e.g. the outer shell deviates from a geometric ellipsoidal shape near the poles and appears to be slightly flattened on each side near the poles in outline view). The medium-sized pores are surrounded by frames, spines can be seen on both poles. These are usually much longer on the pylome pole. The shell is filled by a single (?) spiral with closely spaced whorls, or is totally spongy. Caps sit on the opposite sides of the denser central core. A wide, sometimes tube-like pylome is obvious.

\section{Larcopyle polyacantha amplissima $\mathrm{n}$. subsp.} (P1. 4, figs 1-10)

1975 Lithocarpium fragilis (Stöhr): Petrushevskaya; 572, pl. 4, fig. 4.

1990 Prunopyle sp. D Abelmann: 693-4, pl. 4, fig. 1A/1B.

Derivation of name. The name is from the latin word amplus for splendid, wonderful.

Holotype. Plate 4, figs 6, 7, sample 751A-12-1,98 \#1. Museum für Naturkunde, Mikropaläontologie No. ECO-17.

Description. The sub-cylindrical to elliptical cortical shell is about $170 \mu \mathrm{m}$ long and bears spines on each pole. The inner whorls of the shell are connected only loosely to the cortical shell and frequently are broken free of it, so the central disc can change its position and can be found near a pole. The outer wall is pierced by small- to medium- sized, irregularly arranged pores, which often lack frames. The inner whorls may be single or double, in some specimens the outer (cortical) whorls include incomplete polar caps. A well-developed pylome is present in most specimens.

Occurrence. Early-Mid Miocene, questionable occurrences in Late Miocene.

Remarks. L. p. amplissima is very close to L. p. polyacantha and transitional specimens can be found. It can be distinguished from L. p. polyacantha by the more quadrate, less regular shape of the shell and more evolute whorls.

Larcopyle titan (Campbell \& Clark, 1944) n. comb. (Pl. 4, figs 11-17) 

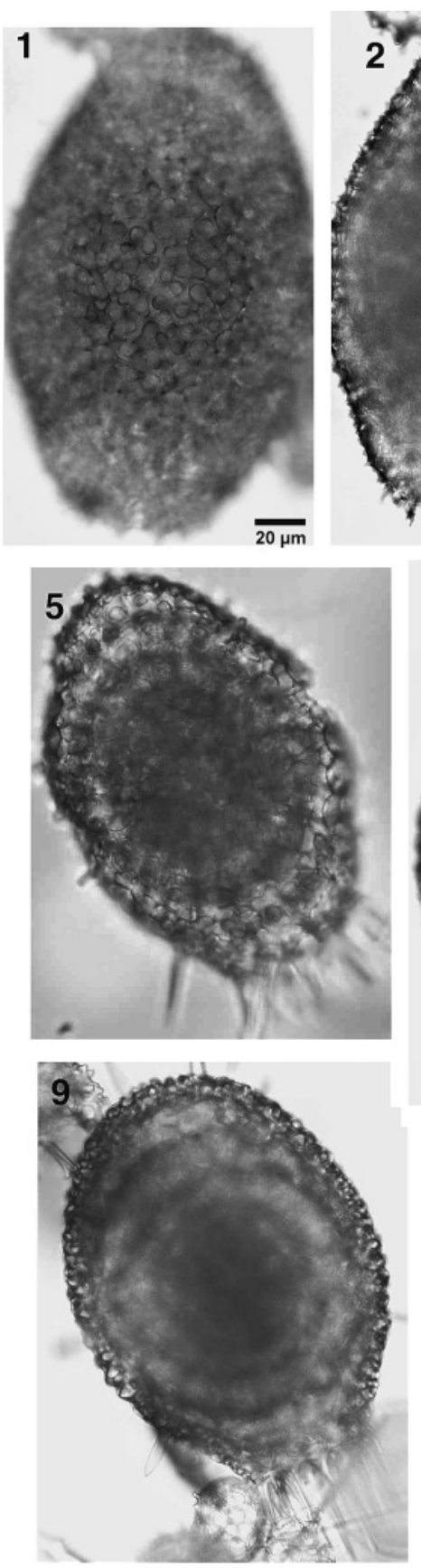
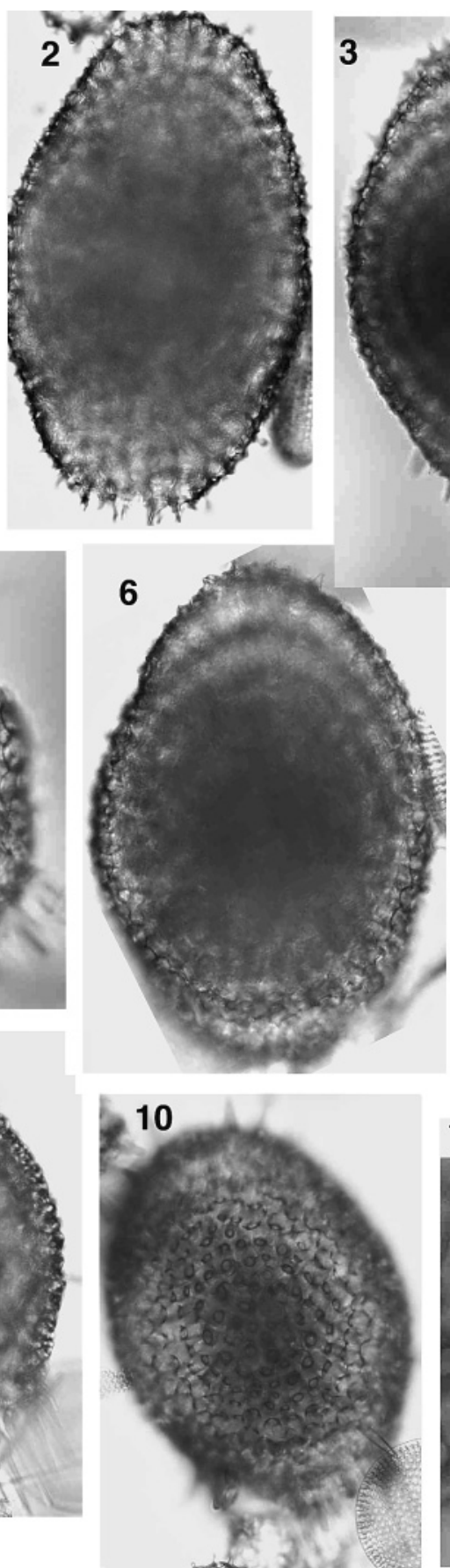
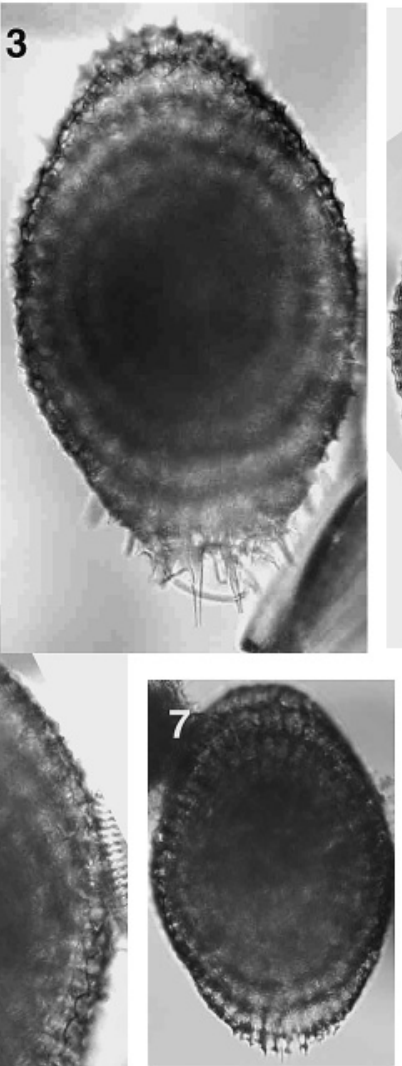

$\overline{20 \mu \mathrm{m}}$

\section{1}

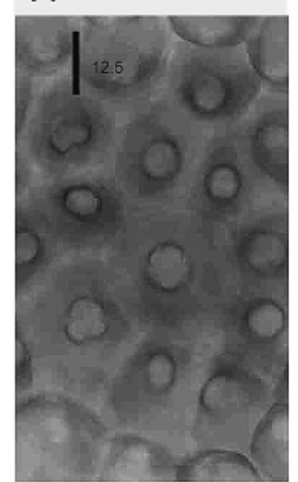

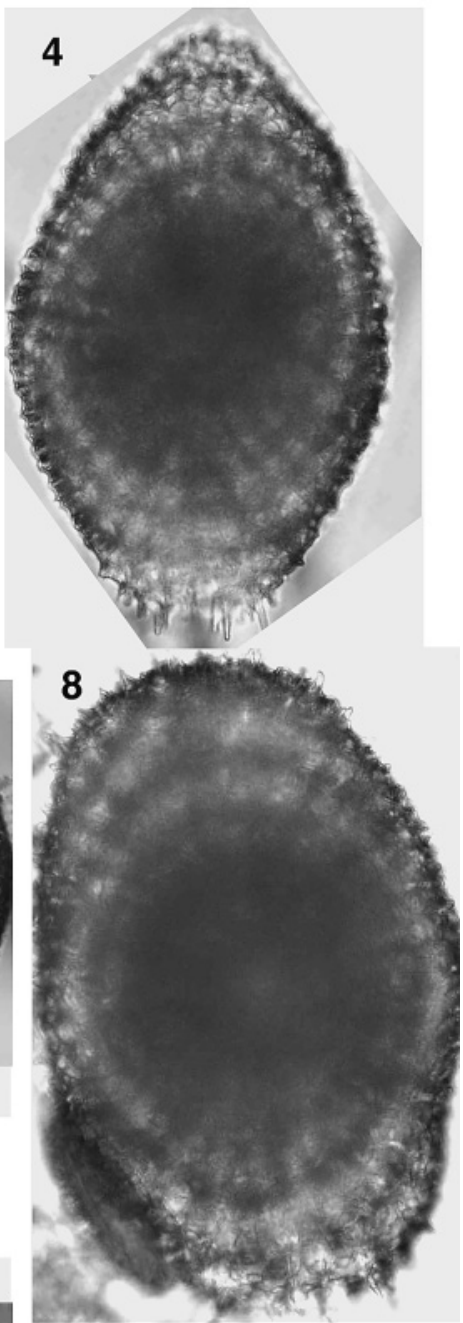

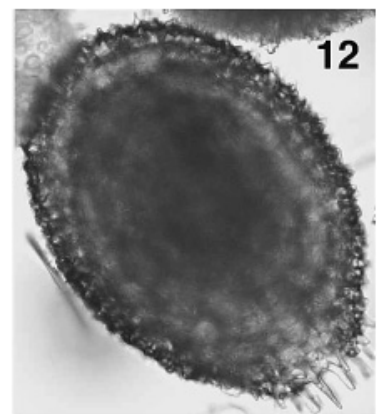

Explanation of Plate 3.

figs 1-12. Larcopyle polyacantha titan: 1, 2, 689B-3H-2,57 (latest Miocene, Weddell Sea) Holotype, Museum für Naturkunde Mikropaläontologie, Accession Number ECO-016; 3, 746A-11-2,53 (Late Miocene, Kerguelen); 4, 746A-11-2,53 (Late Miocene, Kerguelen); 5, 746A-11-2,53 (Late Miocene, Kerguelen); 6, 746A-11-2,53 (Late Miocene, Kerguelen); 7, 746A-11-2,53 (Late Miocene, Kerguelen); 8, 746A-11-2,53 (Late Miocene, Kerguelen); 9, 689B-2-1,53 (Early Pliocene, Weddell Sea, focus on inside of the shell); 10, same specimen, focus on surface; 11, 689B-2-1,53 (Early Pliocene, Weddell Sea, focus on pores); 12, 689B-2-1,53 (Early Pliocene, Weddell Sea) (specimen lacking typical polar caps). Scale bar for all images with fig. 1, except individual scale bars on figs 7 and 11.

Lectotype. A3468-35577, UCMP No. 49553. Same specimen as Campbell \& Clark (1944, pl. 3, fig 2).

Original description. From Campbell \& Clark (1944):
Shell generally ovate, large, with distinct osculum; eggshaped shell stoutly proportioned (1.5-1.6 times its maximum diameter in length), with evenly contoured walls which round off at unmodified apical end and which end antapically 


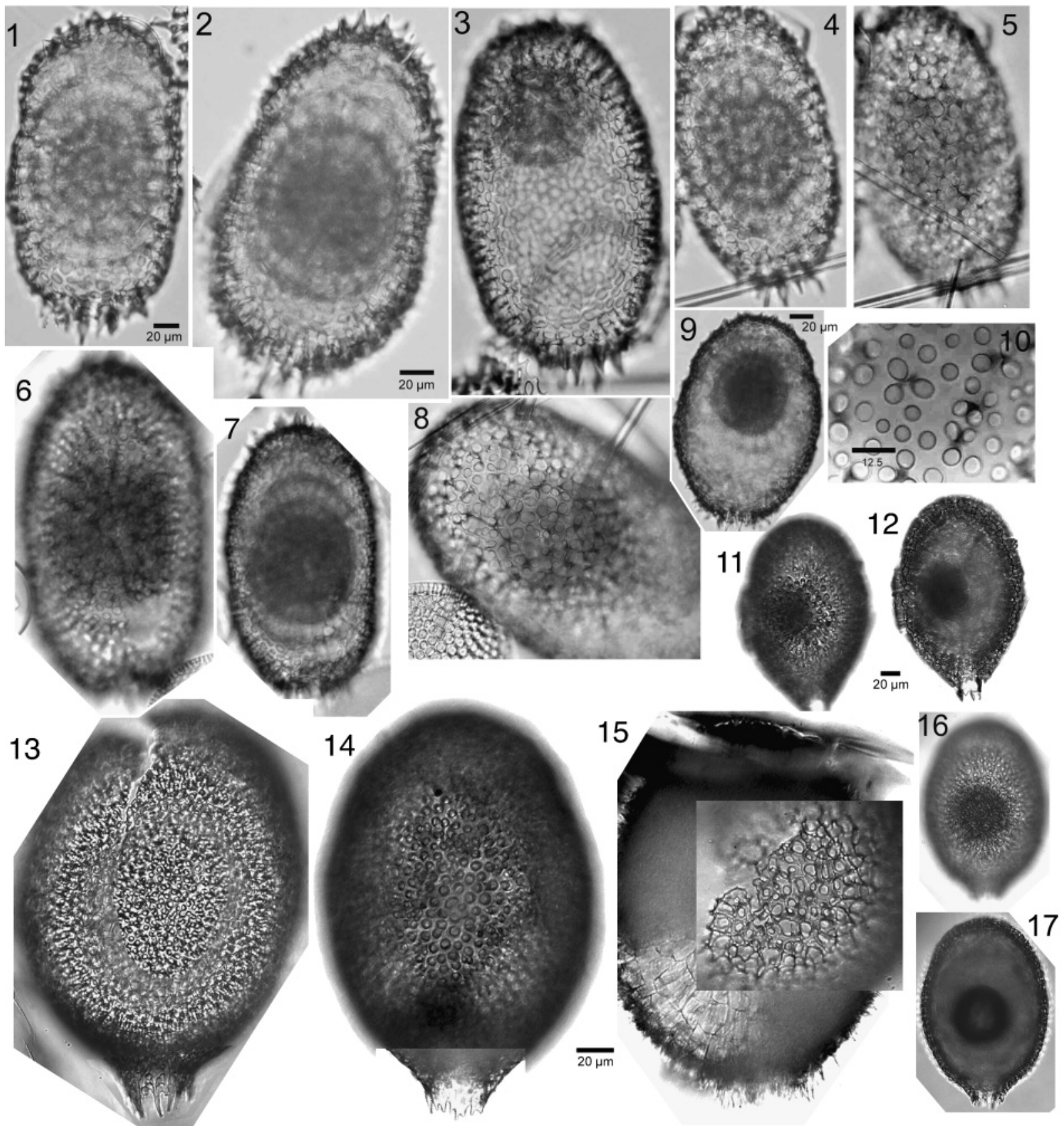

Explanation of Plate 4.

figs 1-10. Larcopyle polyacantha amplissima, Antarctic Neogene: 1, 751A-12-1,98 (Middle Miocene, Kerguelen); 2, 751A-12-1,98 (Middle Miocene, Kerguelen); 3, 751A-12-1,98 (Middle Miocene, Kerguelen ); 4, 5, 751A-12-1,98 (Middle Miocene, Kerguelen); 6, 7, 751A-12-1,98, slide 1, Holotype, Museum für Naturkunde, Mikropaläontologie No. ECO-17; 8, 690B-3-cc (Late Miocene, Weddell Sea); 9, 10, 690B-3-cc (Late Miocene, Weddell Sea). figs 11-17. Larcopyle titan, Campbell \& Clark type series material, Museum of Paleontology, University of California, Berkeley: 11, 12, 3467-3558, S2 0; 13, Lectotype, A3468-35577, UCMP No. 49553, same specimen as Campbell \& Clark (1944, pl. 3, fig. 2), composite image - main image plus overlain central area with focus on cortical shell pores - note break in upper part of shell; 14, A3465-35567, S29, composite image - main image with focus on cortical shell pores plus overlain image of pylome; 15, A3548-35613, 'smear 12', composite image - main image with focus on delicate internal structures, overlay focused on outer cortical pores - note image of upper part of shell disturbed by crack in mounting media; 16, 17, A3460-35562, S24, dark circular area within shell appears to be trapped air bubble. Scale bars for figs 1, 4, 5, 7 with fig. 1; for figs 2 , $3,6,8$ with fig. 2; for figs $11,12,16,17$ with fig. 11; figs $13-15$ with fig. 14 .

at extended osculum; osculum subtubular, very short (less than 0.1 total length in length and 0.2 greatest diameter in diameter), with about 16 projecting, slightly incurved spines around its margin and acting as stays; wall fairly thick; surface smooth; pores of shell very closely set; small (less than $4.4 \mu$ ), circular, at inner ends of tubules connecting with 
surface, tubules mostly directed apically, pores on osculum similar but set farther apart, and not deep-set. Length, $280 \mu$, of tubular osculum, $40 \mu$.

Remarks. In comparison to L. p. titan, true L. titan is more nearly spherical in overall shape, has a largely non-spinose outer shell, and the interior structures are poorly developed, being either weakly spongiose or, in many specimens, nearly hollow. Several specimens from Campbell \& Clark's (1944) type series material are re-illustrated in Plate 4. True L. titan is restricted to earlier Miocene sediments in the Antarctic. Campbell \& Clark comment on a large size range in this species, but this has not been noted in the specimens curated in the Museum in Berkeley, which also are slightly smaller $(c .200 \mu \mathrm{m})$ in length, not counting pylome, than given by Campbell \& Clark (1944).

\section{Larcopyle nebulum $\mathrm{n} . \mathrm{sp}$.}

(P1. 5, figs 1-13)

1975 Lithocarpium polyacantha Petrushevskaya (partim): 572, pl. 3, fig. 6.

Derivation of name. The species name reflects the similarity of the whorl structure to that of a galactic nebula.

Holotype. Plate 5, figs 1-3, 689B-6H-1,116 (Middle Miocene, Weddell Sea). Museum für Naturkunde, Mikropaläontologie No. ECO-18, circle 1.

Description. The shell (about $130-140 \mu \mathrm{m}$ long) has an asymmetric, elliptic shape. In the centre of the shell often a spongy, dark disc can be found, which is surrounded by about three whorls of a single (?) spiral, which are generally irregular in shape. In some specimens the spiral is very weak or absent. A distinct polar cap can be seen in many specimens. The shell surface is rather smooth, due to the irregular-sized pores which lack frames. A wide pylome with teeth is present.

Occurrence. Early Miocene-Mid Miocene.

Remarks. Some specimens are very similar to L. polyacantha, but the shell is smaller and the presence of the spongy disc in the centre is characteristic for L. nebulum.

\section{Larcopyle eccentricum $\mathrm{n}$. sp.} (P1. 6, figs 1-15)

1990 Prunopyle titan Abelmann: 693, pl. 3, fig. 16.

Derivation of name. The name refers to the slightly asymmetric ellipsoidal shape of the shell.

Holotype. Plate 6, figs 1-3, 689B-6H-1, 59-61 cm (Middle Miocene, Weddell Sea). Museum für Naturkunde, Mikropaläontologie No. ECO-19.

Description. The shell is elongate egg-shaped and about $120 \mu \mathrm{m}$ long. The interior of the shell is usually empty, although a delicate set of widely spaced elongated medullary shells can be seen in some specimens. A well-developed pylome with teeth is visible at one pole, which often forms a tube-like structure. The medium-sized pores are circular and rather regularly arranged. They are surrounded by weak frames. The surface varies from smooth to somewhat thorny due to variably developed pore frames. The outer shell wall is rather thin.

Occurrence. Early Miocene-Mid Miocene, scattered, rare questionable occurrences to the Early Pliocene.

Remarks. Differs from Cenolarcopyle fragilis Tan, 1927 (described from tropical sediments of uncertain Tertiary age), despite a superficial similarity in overall shell shape, in that, according to Tan Sin Hok's description, C. fragilis has a pylonid (larnacilla) inner shell, irregularly distributed pores on the cortical shell and is significantly smaller (length $105 \mu \mathrm{m}$ ).

\section{Larcopyle labyrinthusa $\mathrm{n}$. sp.}

$$
\text { (P1. 5, figs 14-24) }
$$

1989 ?Lithelius sp. A (group) Lazarus \& Pallant (partim): 367, pl. 8, fig. 5 (only).

Derivation of name. The name comes from the latin labyrinthus and refers to the labrinthine whorls.

Holotype. Plate 5, figs 16, 17; 689B-6H-1,116 (Middle Miocene, Weddell Sea). Museum für Naturkunde, Mikropaläontologie No. ECO-18, circle 2.

Description. The characteristically indented, sub-spherical shell is about $100 \mu \mathrm{m}$ long. The outer wall is perforated by circular pores of similar size, which are surrounded by weak to strong frames. A double spiral can be seen which forms three widely spaced whorls, including the outer shell. Widely spaced beams connect the whorls internally and a few may project as short, scattered spines in a irregular distribution on the shell surface. The pylome is clearly visible, forming a tube with rather long teeth.

Occurrence. Middle-Late Miocene.

Larcopyle peregrinator $\mathrm{n}$. $\mathrm{sp}$.

(Pl. 7, figs 1-16)

Derivation of name. In reference to the overall resemblance of the shell's streamlined shape and trailing spines to that of a comet or meteor (latin peregrinator - traveller).

Holotype. Plate 7, figs 1-5; 689B-5H-1, 68-70 cm (Middle Miocene, Weddell Sea). Museum für Naturkunde, Mikropaläontologie No. ECO-20.

Description. The moderately large (about $160 \mu \mathrm{m}$ ), spherical to sub-spherical shell has a very rough surface, which is formed by massive frames. The small- to medium-sized, irregularly arranged pores are separated by large bars, the outer wall is rather thick. The double (?) spiral whorls of the inner shell are weak to absent and some specimens are filled only with spongy 

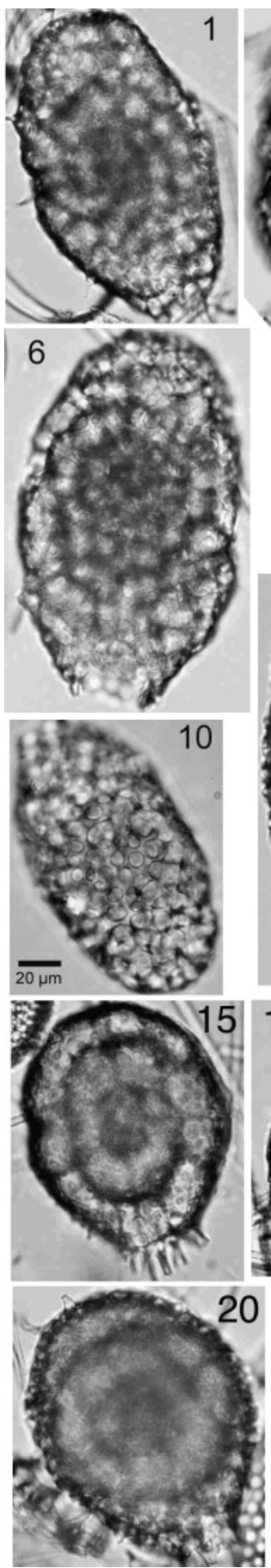
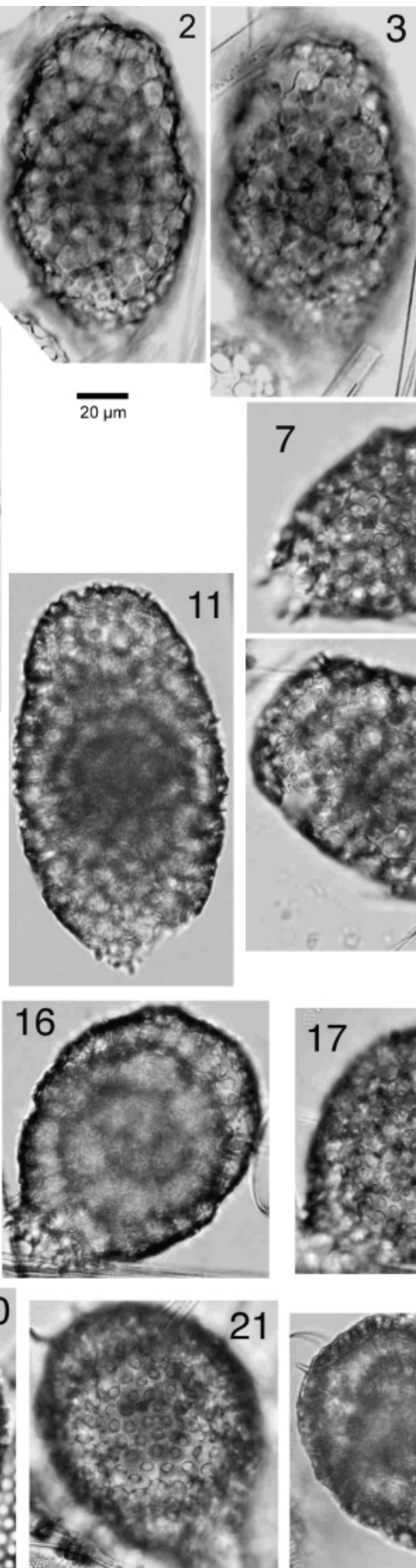
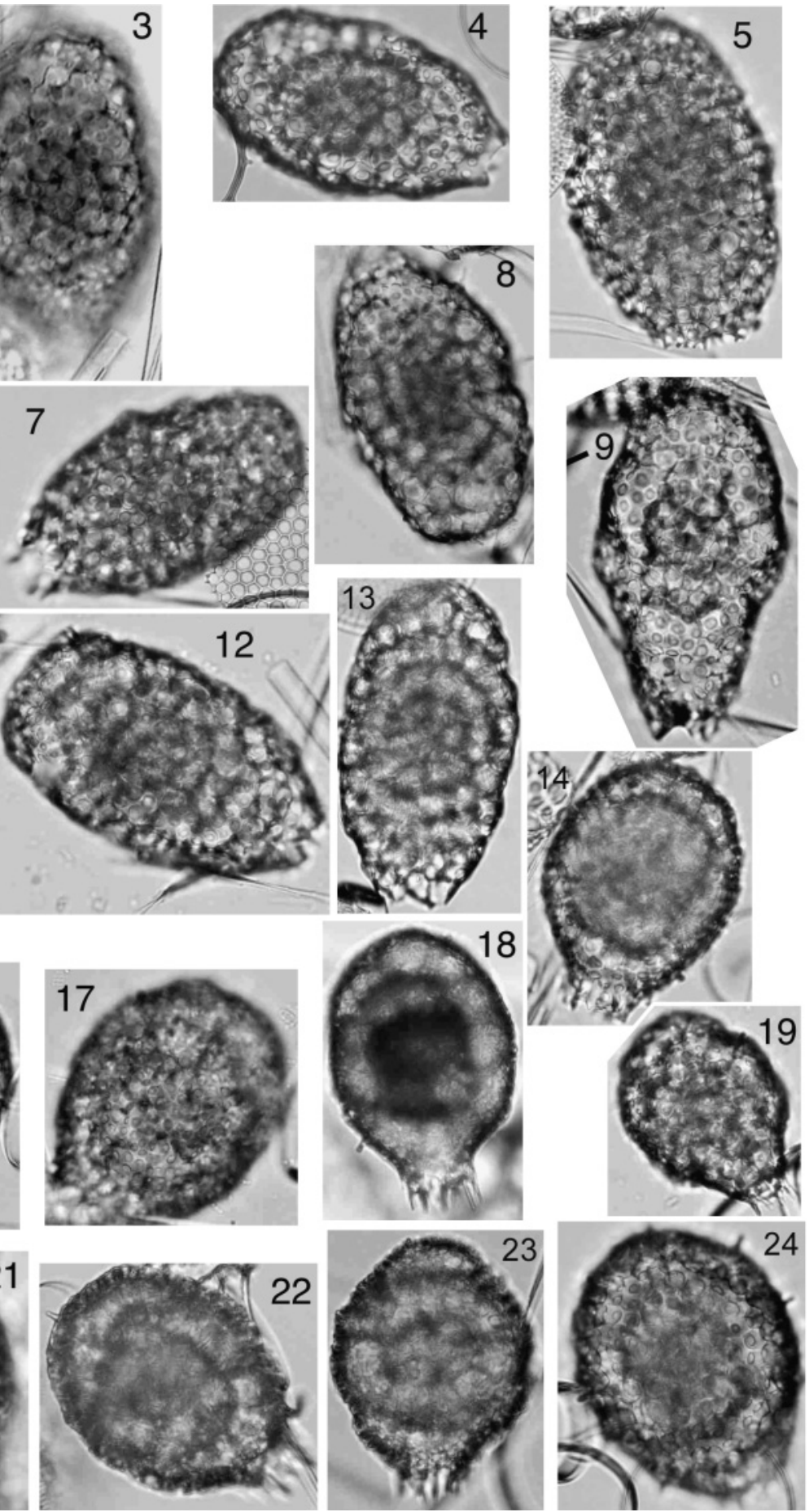

Explanation of Plate 5.

figs 1-13. L. nebulum: 1-3, 689B-6H-1,116 (Middle Miocene, Weddell Sea) Holotype, Museum für Naturkunde, Mikropaläontologie No. ECO-18, circle 1; 4, 751A-12-1,98 (Middle Miocene, Kerguelen); 5, 751A-12-1,98 (Middle Miocene, Kerguelen); 6, 689B-6-1 (Middle Miocene, Weddell Sea); 7, 751A-12-1,98 (Middle Miocene, Kerguelen); 8, 689B-6-1 (Middle Miocene, Weddell Sea); 9, 689B-6-1 (Middle Miocene, Weddell Sea); 10, 751A-12-1,98 (Middle Miocene, Kerguelen, focus on pores); 11, 751A-12-1,98 (Middle Miocene, Kerguelen); 12, 689B-6-1 (Middle Miocene, Weddell Sea); 13, 751A-12-1,98 (Middle Miocene, Kerguelen, focus on spiral). figs 14-24. L. labyrinthusa: 14, 689B-6-1 (Middle Miocene, Weddell Sea); 15, 689B-6-1 (Middle Miocene, Weddell Sea); 16, 17, 689B-6H-1,116 (Middle Miocene, Weddell Sea) Holotype, Museum für Naturkunde, Mikropaläontologie No. ECO-18, circle 2; 18, 690C-3-cc (Late Miocene, Weddell Sea); 19, 689B-6-1 (Middle Miocene, Weddell Sea); 20, 21, 689B-6-1 (Middle Miocene, Weddell Sea, focus on inside of the shell); 22, 689B-4-6,59 (Late Miocene, Weddell Sea); 23, 689B-4-6,59 (Late Miocene, Weddell Sea); 24, 751A-12-1,98 (Middle Miocene, Kerguelen). Scale bar for figs 10 and 14 with fig. 10, for all others under fig. 2. 

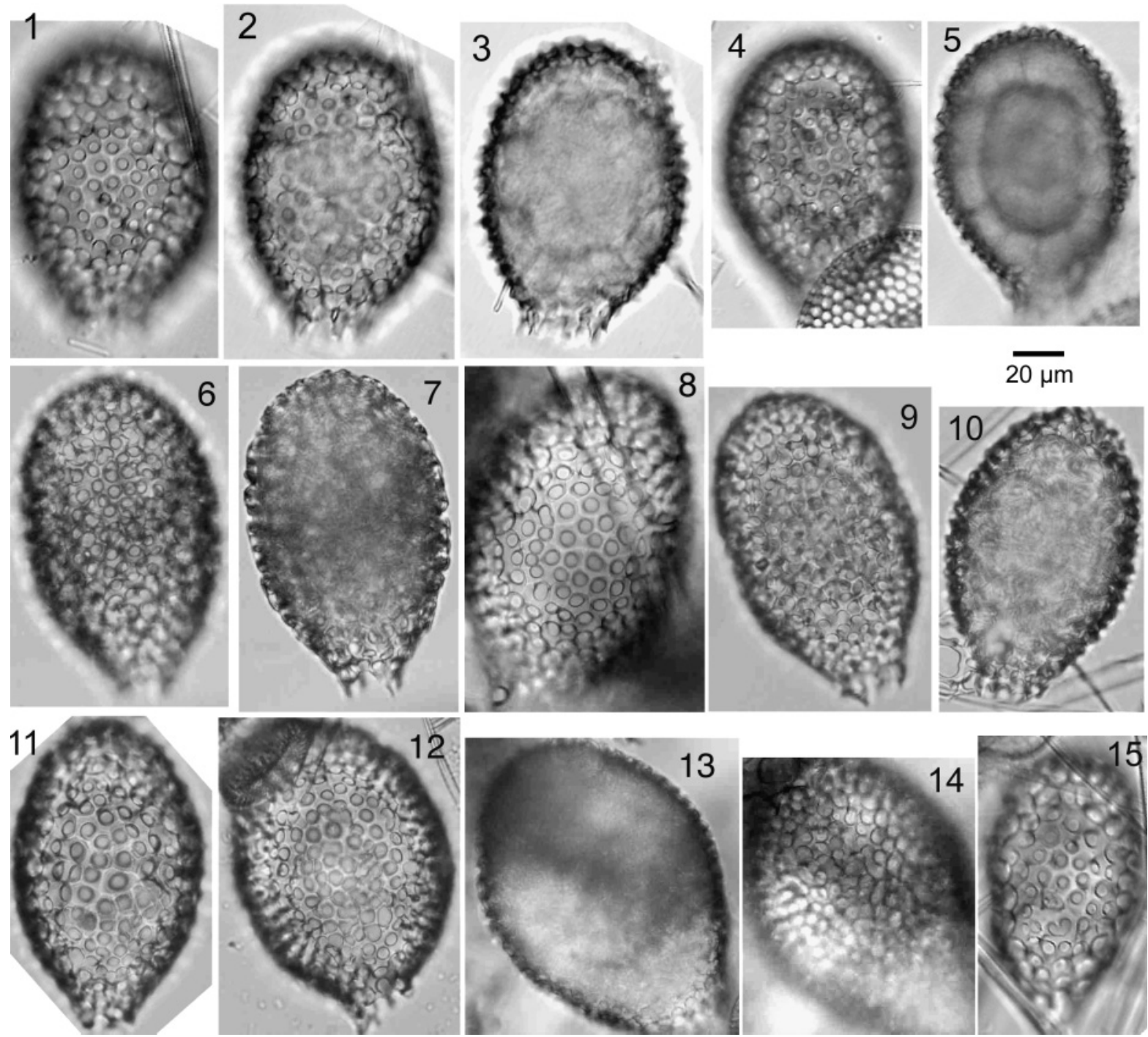

Explanation of Plate 6.

figs 1-15. L. eccentricum: 1-3, 689B-6H-1, 59-61 cm (Middle Miocene, Weddell Sea) Holotype, Museum für Naturkunde, Mikropaläontologie No. ECO-1 9; 4, 5, 689B-6H-1, 59-61 cm (Middle Miocene, Weddell Sea); 6, 7, 689B-6-cc (Middle Miocene, Weddell Sea); 8, 689B-6-cc (Middle Miocene, Weddell Sea); 9, 690B-5-cc (Middle Miocene, Weddell Sea); 10, 689B-6-1 (Middle Miocene, Weddell Sea); 11, 690B-5-cc (Middle Miocene, Weddell Sea); 12, 689B-6-1 (Middle Miocene, Weddell Sea); 13, 14, 689B-6-cc (Middle Miocene, Weddell Sea); 15, 689B-6H-1, 59-61 cm (Middle Miocene, Weddell Sea). Scale bar is identical for all images.

meshwork. Clusters of short polar spines can be found in some specimens. A pylome is not visible.

Occurrence. Early Miocene-Late Miocene, questionable occurrences into Pliocene.

Remarks. The absence of a clear pylome in this form means that its inclusion in this study as a prunoid is not entirely justified. However, the spiral inner shell, complete outer shell and presence, in at least some specimens, of clusters of short polar spines suggest an affinity to the other prunoids in this study. Assignment to the lithelids, however, would also be possible.

\section{Larcopyle augusti n. sp.}

(Pl. 8, figs 1-13)
1975 Sponguridae gen. sp. D Petrushevskaya: 577, pl. 4, fig. 1.

Derivation of name. In reference to the extended external shell or mantle, which gives this form a 'majestic dignity or grandeur' (Webster's New Collegiate Dictionary).

Holotype. Plate 8, figs 1, 2; 751A-9-5,98 \#1 (Late Miocene, Kerguelen). Museum für Naturkunde, Mikropaläontologie No. ECO-21.

Description. The sub-cylindrical skeleton is about $150 \mu \mathrm{m}$ long. There is an unusually large distance between the outer wall and the central layers of the shell. In many specimens the outer wall is absent, either due to breakage or incomplete development. The central shell shows caps, which are arranged one on top of 

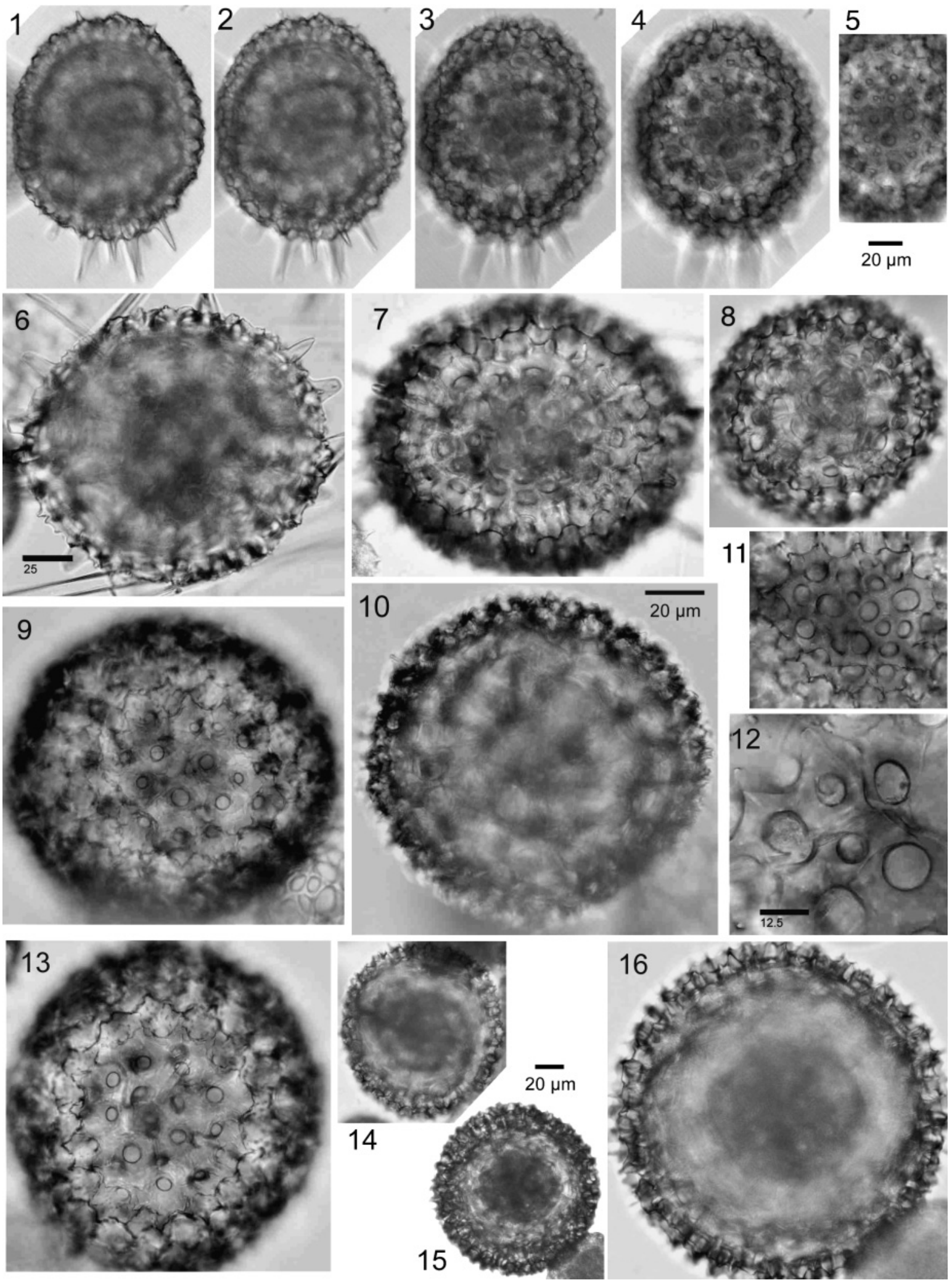

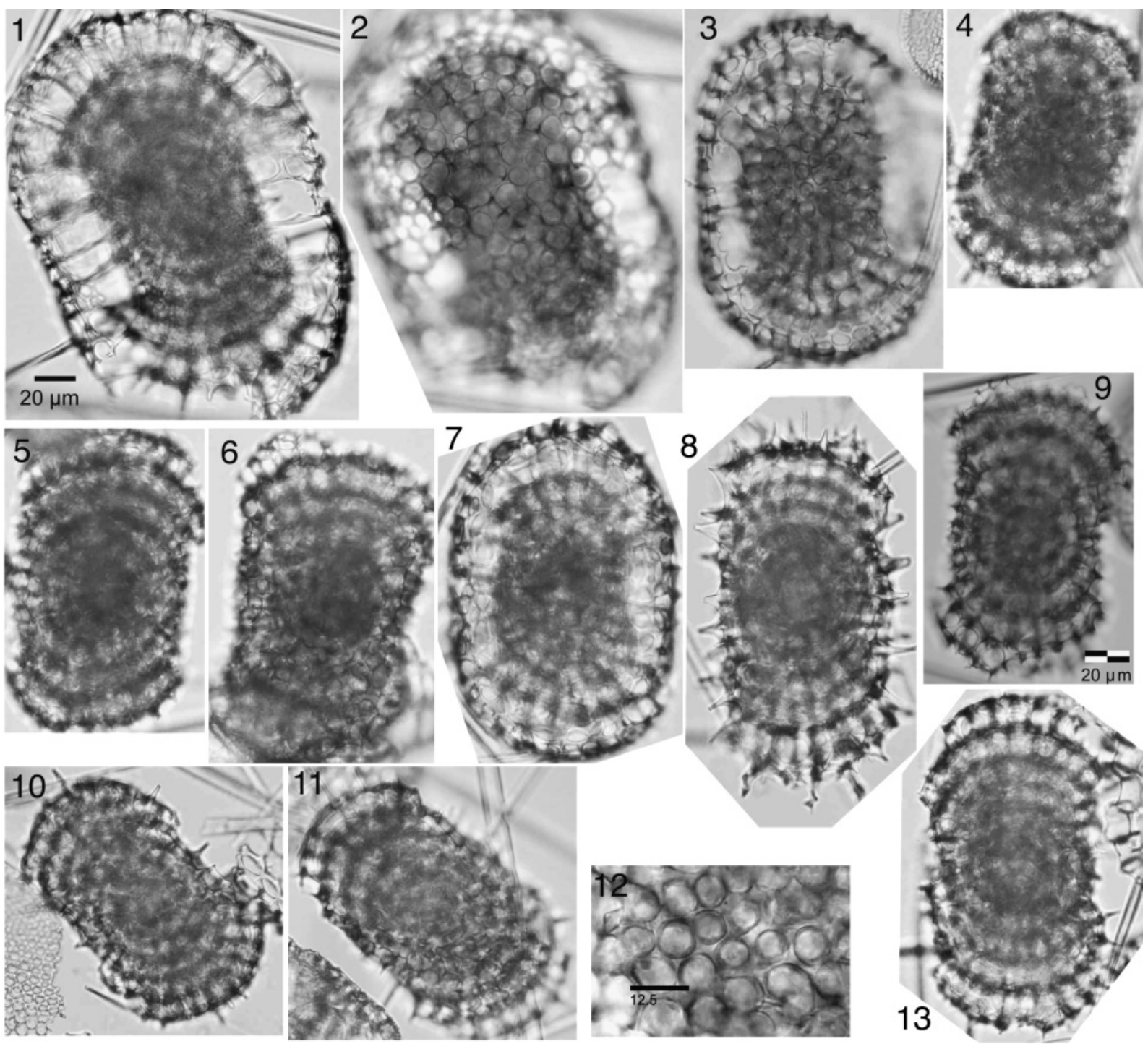

Explanation of Plate 8.

figs 1-12. L. augusti: 1, 2, 751A-9-5,98 \#1 (Late Miocene, Kerguelen) Holotype, Museum für Naturkunde, Mikropaläontologie No. ECO-21; 3, 690C-3-cc (Late Miocene, Weddell Sea); 4, 690C-3-cc (Late Miocene, Weddell Sea); 5, 690C-3-cc (Late Miocene, Weddell Sea); 6, 690C-3-cc (Late Miocene, Weddell Sea); 7, 689B-6-1 (Middle Miocene, Weddell Sea); 8, 751A-9-5, 98 (Late Miocene, Kerguelen); 9, 751A-9-6, 98 (Late Miocene, Kerguelen); 10, 689B-6-1 (Middle Miocene, Weddell Sea); 11, 751A-9-5,98 (Late Miocene, Kerguelen); 12, 689B-6-1 (Middle Miocene, Weddell Sea); 13, 689B-6-1 (Middle Miocene, Weddell Sea). Scale bar for fig. 12 with 12; for all others next to fig. 1 .

the other, so the shell looks like a biconcave lens in crosssection. The thin outer wall is perforated by large circular pores of irregular size, which lack frames. It is connected with the central shell by long spines. A pylome is not obvious. Late Miocene specimens become more spongy.

Occurrence. Middle Miocene-Late Miocene.
Remarks. As noted under L. pylomaticus, L. augusti appears to evolve into $L$. pylomaticus in the Late Miocene. Transitional forms are noted separately in the range chart (Table 1).

\section{Larcopyle pylomaticus (Riedel) n. comb., 1958}

(Pl. 9, figs 1-12)

1958 Spongurus pylomaticus Riedel: 226, pl. 1, figs 10/11.

Explanation of Plate 7.

figs 1-16. L. peregrinator: 1-5, 689B-5H-1, 68-70 cm (Middle Miocene, Weddell Sea) Holotype, Museum für Naturkunde, Mikropaläontologie No. ECO-2 0; 6, 689B-6H-1 (Middle Miocene, Weddell Sea); 7, 689B-6H-1 (Middle Miocene, Weddell Sea); 8, 689B-3H-2, 57 cm (Early Pliocene, Weddell Sea); 9, 10, 689B-2H-1, 53 cm (Early Pliocene, Weddell Sea); 11, 689B-6H-1 (Middle Miocene, Weddell Sea); 12, 689B-6H-1 (Middle Miocene, Weddell Sea); 13, 689B-2H-1, $53 \mathrm{~cm}$ (Early Pliocene, Weddell Sea); 14, 690C-3-CC (Late Miocene, Weddell Sea); 15, 751A-12H-1, 98 cm (Middle Miocene, Kerguelen Plateau); 16, 751A-12H-1, $98 \mathrm{~cm}$ (Middle Miocene, Kerguelen Plateau), Scale bar for figs 1-5, 8, 11 with fig. 5; for figs $6,7,9-11,13,16$ with fig. 10 ; for fig. 12 with 12 ; for figs 14 , 15 with fig. 15 . 

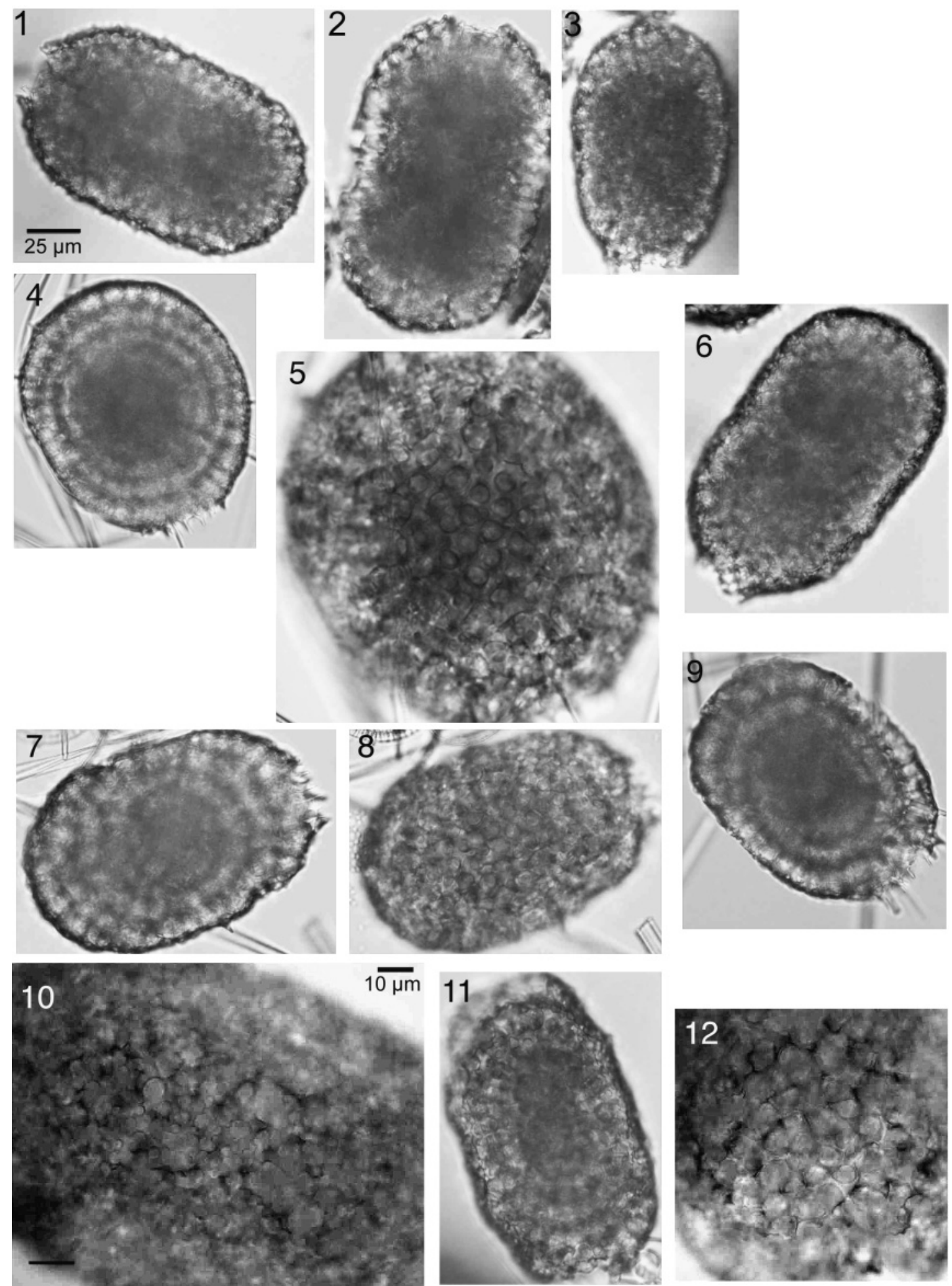

Explanation of Plate 9.

figs 1-12. L. pylomaticus: 1, 689B-2-1,53 (Early Pliocene, Weddell Sea); 2, 689B-2-1,53 (Early Pliocene, Weddell Sea); 3, 689B-2-1,53 (Early Pliocene, Weddell Sea); 4, 5 751A-9-5,98 (Late Miocene, Kerguelen); 6, 689B-2-1,53 (Early Pliocene, Weddell Sea); 7, 8, 689B-6-1 (Middle Miocene, Weddell Sea); 9, 746A-11-2,53 (Late Miocene, Kerguelen); 10, 689B-2-1,53 (Early Pliocene, Weddell Sea, focus on pores); 11, 689B-3H-2,57 (Early Pliocene, Weddell Sea); 12, 689B-2-1,53 (Early Pliocene, Weddell Sea, focus on pores). Scale bar for figs 5, 10 and 12 next to fig. 10, all others next to fig. 1. 

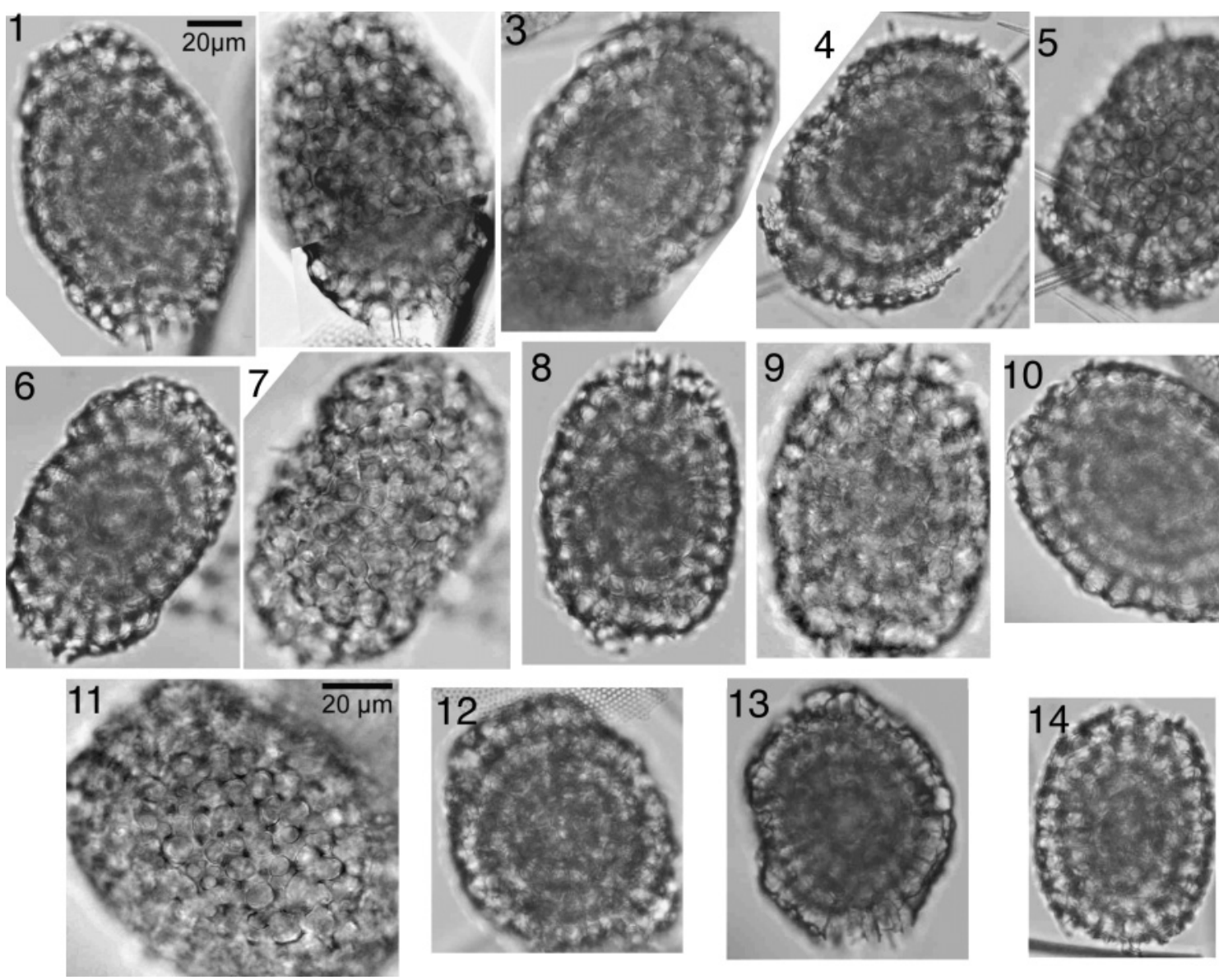

Explanation of Plate 10.

figs 1-14. L. weddellium: 1, 2, 745B-10-2,53 (Pleistocene, Kerguelen) Holotype - (1) intermediate focus showing whorls, (2) composite image showing pores and pylome, Museum für Naturkunde, Mikropaläontologie No. ECO-22; 3, 745B-21-4,53 (Early Pliocene, Kerguelen); 4, 5, 751A-9-5,98 (Late Miocene, Kerguelen); 6, 7, 689B-2-1,53 (Early Pliocene, Weddell Sea); 8, 9, 745B-10-2,53 (Pleistocene, Kerguelen); 10, 11, 689B-3H-2,57 (Early Pliocene, Weddell Sea); 12, 746A-11-2,53 (Late Miocene, Kerguelen); 13, 690B-3-cc (Late Miocene, Weddell Sea); 14, 745B-10-2,53 (Pleistocene, Kerguelen). Scale bar with fig. 1 for all images except fig. 11, which has separate scale.

1975 Spongurus pylomaticus Riedel: Petrushevskaya; 577, pl. 7, fig. 4.

Description. See also original description by Riedel (1958). The sub-cylindrical or elliptical shell is about $130 \mu \mathrm{m}$ long and has a dark appearance in the light microscope. The more or less spongy outer wall consists of small pores which are arranged close together and lack frames. In Pliocene specimens the inside of the shell is filled with spongy meshwork, whereas older specimens show a double (?) spiral with constantly spaced whorls. These, in turn, appear to intergrade with coeval Late Miocene specimens of L. augusti. The shell has a well-developed, wide pylome with teeth.

Occurrence. Late Miocene-Pleistocene.

Remarks. Some specimens are similar to $L$. weddellium, but they have smaller pores and a darker appearance than $L$. weddellium, as well as a different shape. Spongurus pylomaticus has been reported from both the Antarctic (Indian Ocean - Riedel, 1958; South Pacific - Petrushevskaya, 1975; Falkland Plateau -
Weaver, L71, 1983) and North Pacific (Morley, L86, 1985), but only three prior illustrations of this species (one drawing and two photographs, in these publications) are known to the authors. With the exception of DSDP Site 278 in the South Pacific, all named specimens reported to date have been of Pliocene or younger age and the illustrated specimens represent the spongy variant of the form. The presence of whorls in older members of this form, which appears to be part of an evolutionary lineage with the mid-Miocene form of $L$. augusti, plus the well-developed pylome, together indicate that it should not be assigned to Spongurus, which was erected by Haeckel (1862) for forms without internal structures or an external lattice wall (and with no mention of a pylome).

\section{Larcopyle weddellium $\mathrm{n}$. sp.}

(Pl. 10, figs 1-14)

1984 ?Spongurus sp. A Nigrini \& Lombari: 33, pl. 5, figs 1a, b.

Derivation of name. The species is named after the Weddell Sea, where this morphotype was first encountered. 

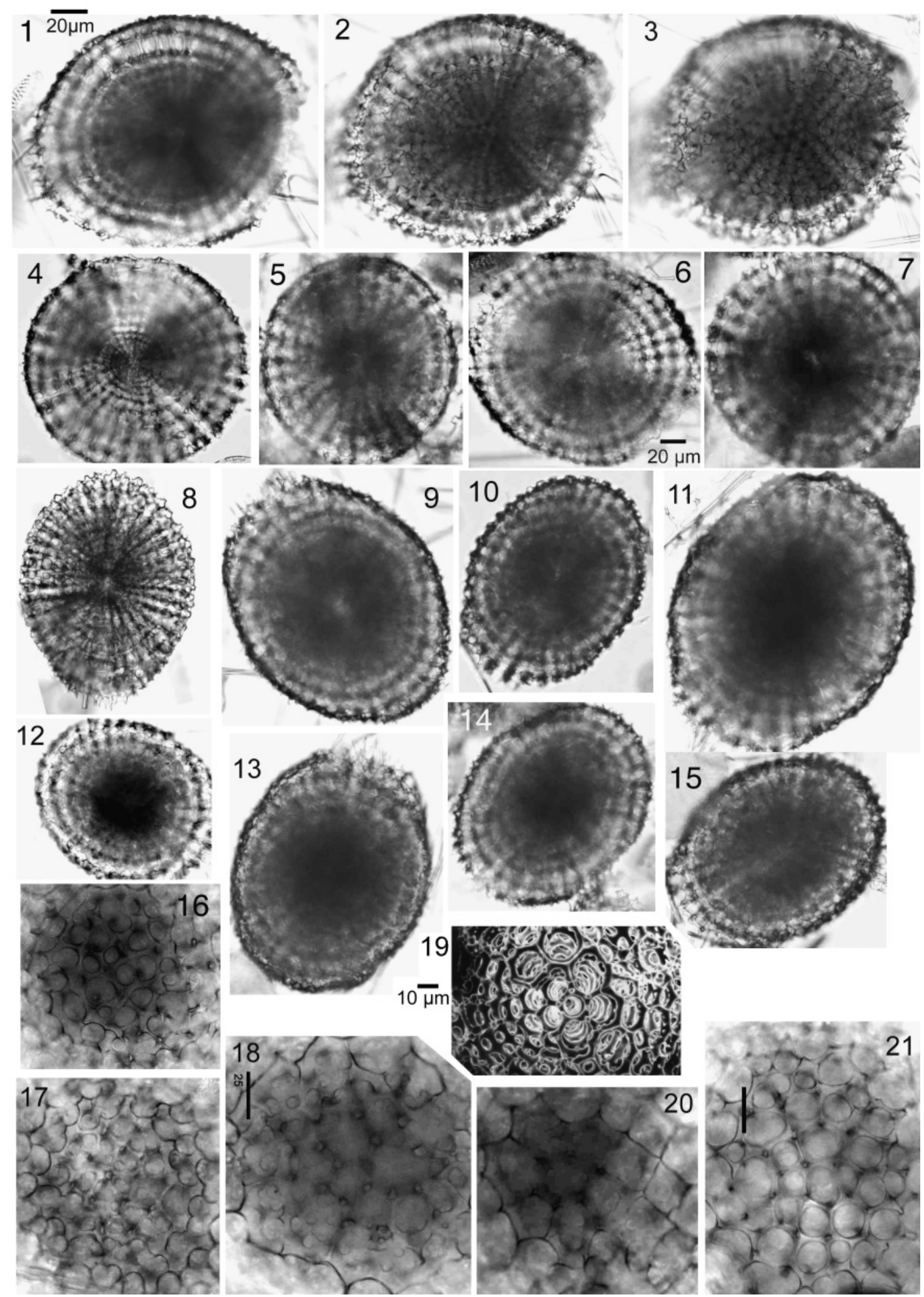
Holotype. Plate 10, figs 1, 2; 745B-10-2,53 (Pleistocene, Kerguelen). Museum für Naturkunde, Mikropaläontologie No. ECO-22.

Description. The small shell (about $110 \mu \mathrm{m}$ ) has a rather asymmetrical, ellipsoidal shape. The large pores are arranged close together, frames are absent in most specimens. A double spiral with closely spaced whorls gives the shell a compact appearance. Characteristically there are distinct caps on one or both poles and the whorls are not completely smooth, but have sharper bends and flattened regions. A wide pylome, often with teeth or a cluster of short spines, is usually present.

Occurrence. Late Miocene-Pleistocene, scattered occurrences in the Mid Miocene.

Remarks. Larcopyle weddellium is superficially similar to Lithelius minor Jörgensen, 1900, and/or similar lithelid forms, such as Lithelius spiralis Haeckel, 1887, in that all of these forms are built of compact spiral whorls of lattice shell. L. weddellium, however, is consistently ellipsoidal, has somewhat angular whorls, frequently has partially formed whorls at the pole ends of the shell and appears to possess a pylome, as indicated by the weakly expressed cluster of short spines or teeth at one end of the ellipsoidal shell. Larcopyle weddellium is also similar to incomplete specimens of Larcopyle pylomaticus n. comb., but can be distinguished by the characteristically asymmetrical shape of the shell - which is absent in L. pylomaticus - and its larger pores. The specimens illustrated by Nigrini \& Lombari (1984) appear to be conspecific with $L$. weddellium described here, but they will not be formally synonymized without the actual material being examined.

\section{Larcopyle hayesi Chen, 1975}

(P1. 11, figs 1-21)

Neotype. Plate 11, figs 1-3; 751A-9H-5, 98-102 cm. Museum für Naturkunde, Mikropaläontologie No. ECO-23.

\section{Original description From Chen (1975):}

Description: Shell prune-shaped, consisting of radiating spines and densely spiral shell. Pylome circular, large, and surrounded by 12-19 conical spines. Pores framed by hexagonal bars and aligned with the radiating spines through each layer of the spiral shell.

Measurements based on 35 specimens from Samples 27421-3, 54-64 cm; 274-21, CC; 274-22, CC; and 274-23, CC: major axis of the shell $270 \mu-315 \mu$; minor axis of the shell,
$207 \mu-252 \mu$; diameter of pylome, $89 \mu-101 \mu$. Remarks: This species is characterised by its hexagonally framed pores, and densely spiral shell.

Remarks. This species is quite variable in morphology and is divided here into two informal varieties, which have somewhat different stratigraphic ranges and geographical distribution. No formal designation of a subspecies is made, however, as there is continuous gradation between the forms and the differences between them, although real, may also possibly be produced in some specimens by differences in preservation. A more detailed examination of the structure of the shell, including interior features, will be needed before a biologically well-founded subdivision of this morphological group is possible. Note: The original type material of Chen (1975) was lost before being deposited. Therefore, a replacement type specimen is designated here. The specimen chosen shows a common morphology that is nearly intermediate between the two informally defined varieties, $L$. h. 'hayesi' and L. h. 'irregularis', although it would be assigned to the $L$. h. hayesi variety. More distinctive examples of both varieties are illustrated by other specimens in Plate 11.

\section{Larcopyle hayesi variety 'hayesi'}

(Pl. 11, figs 1-8, 18-20)

1975 Prunopyle hayesi Chen, partim: 454, pl. 9, figs 4, 5 only. 1975 Ommatodiscus haeckeli Petrushevskaya: 572, pl. 32.

1990 Prunopyle hayesi Chen: Abelmann; 693, pl. 3, fig. 14.

Description. The large shell $(250-300 \mu \mathrm{m})$ is spherical to elliptical and sometimes has small thorns. The large pores are surrounded by pentagonal and hexagonal frames. Some pores appear to be subdivided into smaller pores by internal bar networks. The single spiral has up to 10 , occasionally even more, closely spaced whorls. The levels of the whorls are connected by aligned beams, forming a characteristic radial pattern of dark bands (the beams) and white stripes (pore regions) when viewed in transmitted light. The meshwork of bars and beams can, in some of the intermediate spirals, create hub and spoke types of latticework, with a radial beam as the hub and triangular pores (apices directed inward) surrounding it. In the centre of the shell often a spongy mass can be seen which obscures the innermost whorls, although this is less well developed than in L. h. 'irregularis'. A pylome is weak or absent, although many specimens have a few external spines, and often one rather stout spine with a flat tip extending from the pylome region.

Occurrence. Early-Late Miocene.

Explanation of Plate 11.

figs 1-8. L. hayesi 'hayesi': 1-3, 751A-9H-5, 98-102 cm Neotype, Museum für Naturkunde, Mikropaläontologie No. ECO-23; 4, 689D-4-cc (Middle Miocene, Weddell Sea); 5, 689D-4-cc (Middle Miocene, Weddell Sea); 6, 751A-9-5,98 (Late Miocene, Kerguelen); 7, 689D-4-cc (Middle Miocene, Weddell Sea); 8, 689B-5H2, 56-58 cm (Middle Miocene, Weddell Sea). figs 9-17. L. h. 'irregularis': 9, 751A-9-5,98 (Late Miocene, Kerguelen); 10, 689B-6-1,59 (Middle Miocene, Weddell Sea); 11, 746A-11-2,53 (Late Miocene, Kerguelen); 12, 751A-9-5,98 (Late Miocene, Kerguelen); 13, 751A-9-5,98 (Late Miocene, Kerguelen); 14, 689D-4-cc (Middle Miocene, Weddell Sea); 15, 689B-6-1 (Middle Miocene, Weddell Sea); 16, 751A-9-5,98 (Late Miocene, Kerguelen); 17, 689B-6-1 (Middle Miocene, Weddell Sea). figs 18-20. L. hayesi 'hayesi': 18, 746A-11-2,53 (Late Miocene, Kerguelen); 19, (sample unknown), SEM showing aligned pores between whorls; 20, 689D-4-cc (Middle Miocene, Weddell Sea); 21, 751A-12-1,98 (Middle Miocene, Kerguelen), pores of specimen transitional between varieties. Scale bar for figs 1-3, 8, 11 with fig. 1; for figs 4-7, 9-10, 12-15 with fig. 6; for figs 16-18, 20-21 with fig. 18; for fig. 19 to left of image. 
Remarks. $L$. $h$. 'hayesi' is close to $L$. $h$. 'irregularis', but can be distinguished by its more strongly developed pore alignment (white-striped appearance) and more spherical shape, somewhat larger size, larger pores on the cortical shell and less spongy centre.

\section{Larcopyle hayesi variety 'irregularis'} (P1. 11, figs 9-17)

1975 Prunopyle hayesi Chen, partim: 454, pl. 9, fig. 3 only. 1989 Prunopyle sp. A Lazarus \& Pallant: 368, pl. 8, fig. 7. 1990 Prunopyle sp. A Abelmann: 693, pl. 3, fig. 15.

Description. The large $(250-300 \mu \mathrm{m})$ shell has an ellipsoidal shape. A single (?) spiral with closely spaced whorls surrounds a central spongy mass. Medium-sized pores with frames perforate the outer wall. The beams, particularly in the inner half of the shell are not so well aligned between whorls, so the characteristic white stripes of $L . h$. 'hayesi' are only developed in the outer part of the shell in $L$. $h$. 'irregularis'. A wide pylome with teeth is obvious in most specimens. Transitional specimens to $L . h$. 'haysei' are very common.

Occurrence. Oligocene-early Pliocene, questionable occurrences in more recent sediments.

Remarks. $L$. $h$. 'hayesi' has so far been illustrated only from the Antarctic, where it is best developed in the Early to Middle Miocene. L. h. 'irregularis', by contrast, seems to be relatively cosmopolitan in Mid-Cenozoic sediments, at least in high latitude regions. Specimens of $L$. $h$. 'hayesi' may, if the centre part of the shell is not fully cleaned of sediment, appear spongy and thus much like L. h. 'irregularis'.

\section{CONCLUSIONS AND CLOSING COMMENTS}

The morphological complexity and variability of forms in the Litheliidae and related groups present problems for analysis. This has been complicated by an artificial, overly rigid geometric approach to classification of forms by Haeckel and subsequent workers, and by a much too broad definition of important characters, such as the pylome, by Dreyer and others which has conflated homologous and analogous features. Therefore, it has been decided to begin anew and this study has primarily described clusters of morphotypes at the species level which may in the future serve as the basis for a higher-level taxonomy. The study is restricted to prunoid forms, here defined as possessing a well-developed, generally ellipsoidal external shell, in most instances with a pylome, and with spongy, spiral or pylonid internal shell structures. A survey of the previous literature reveals that only one genus name - Larcopyle Dreyer (1889) -appears to belong validly to this group.

In this initial survey, the primary goal was not to achieve a deep understanding of the shell form and its evolutionary development, but merely to identify some useful morphotypes within the group as a whole. Therefore, the focus has been on identifying forms whose easily visible morphological characteristics are distinctive enough to allow rapid assignment to taxa. A total of 14 species or subspecies-level taxa from Neogene Antarctic sediments are described here, nine of which are new.
These definitions cover the majority of specimens of prunoids encountered in these sediments and, hopefully, will significantly improve the resolution of radiolarian faunas in applied biostratigraphic and palaeoceanographic research.

\section{ACKNOWLEDGEMENTS}

The authors would like to thank Joe Morley for providing a set of radiolarian slides from Site 881 for use in this study, Annika Sanfilippo for providing literature, Ken Finger for his support of the senior author while examining the original Campbell \& Clark materials in the UC Berkeley Museum, and two anonymous reviewers for constructive comments on the ms. This work was supported in part by a Swiss Federal Institute of Technology (ETH) visiting scientist grant to IP, and a German Science Foundation grant to DBL (DFG grant LA-1191/1).

\section{Manuscript received 23 May 2003 Manuscript accepted 28 April 2005}

\section{REFERENCES}

Abelmann, A. 1990. Oligocene to Middle Miocene radiolarian stratigraphy of southern high latitudes from Leg 113, sites 689, and 690, Maud Rise. In: Barker, P.F. \& Kennett, J.P. (Eds), Proceedings of the Ocean Drilling Program, Scientific Results, 113. Ocean Drilling Program, College Station, TX, 675-708.

Abelmann, A. 1992. Early to Middle Miocene radiolarian stratigraphy of the Kerguelen Plateau, Leg 120. In: Wise, S.W. Jr \& Schlich, R. (Eds), Proceedings of the Ocean Drilling Program, Scientific Results, 120. Ocean Drilling Program, College Station, TX, 757-783.

Benson, R.N. 1966. Recent Radiolaria from the Gulf of California. PhD thesis. University of Minnesota, 557pp.

Bjørklund, K.R. 1977. Actinomma haysi, n.sp., its Holocene distribution and size variation in Atlantic Ocean sediments. Micropaleontology, 23 (1): 114-126.

Campbell, A.S. 1954. Radiolaria. In: Moore, R.C. (Ed.), Treatise on Invertebrate Paleontology, Part. D, Protista 3. Geological Society of America and University of Kansas Press, Lawrence, Kansas, 11-195.

Campbell, A.S. \& Clark, B.L. 1944. Miocene radiolarian faunas from southern California. Geological Society of America Special Paper, 51: $1-76$.

Caulet, J.P. 1991. Radiolarians from the Kerguelen Plateau, Leg 119. In: Barron, J. \& Larsen, B. (Eds), Proceedings of the Ocean Drilling Program, Scientific Results, 119. Ocean Drilling Program, College Station, TX, 513-546.

Chen, P.H. 1975. Antarctic Radiolaria. In: Hayes, D.E. \& Frakes, L.A. (Eds), Initial Reports of the Deep Sea Drilling Project, 28. US Government Printing Office, Washington, D.C, 437-513.

Clark, B.L. \& Campbell, A.S. 1942. Eocene radiolarian faunas from the Monte Diablo area, California. Geological Society of America Special Paper, 39: 1-112.

De Wever, P., Dumitrica, P., Caulet, J.P., Nigrini, C. \& Caridroit, M. 2002. Radiolarians in the Sedimentary Record. Gordon and Breach, Amsterdam, 533pp.

Dreyer, F. 1889. Die Pylombildungen in der vergleichend-anatomischer und entwicklungsgeschichtlicher Beziehung bei Radiolarien und bei Protisten überhaupt, nebst System ünd Beschreibung neuer ünd der bis jetzt bekannten pylomatischen Spumellarien. Jenaische Zeitschrift fur Naturwissenschaft, 23: 77-214.

Dreyer, F. 1890. Die Tripoli von Caltanisetta (Steinbruch Gessolungo) auf Sizilien. Jenaische Zeitschrift fur Naturwissenschaft, 24: 1-79.

Ehrenberg, C.G. 1854. Mikrogeologie. Das Erden und Felsen schaffende Wirken des unsichtbar kleinen selbststandigen Lebens auf der Erde. Leopold Voss, Leipzig, xxviii+374p., Atlas, 31p. Fortsetzung (1856), 88 p. +1 p. errata.

Ehrenberg, C.G. 1859. Kurze Characteristik der 9 neuen Genera ünd der 105 neuen Species des agaischen Meeres ünd des Tiefgrundes des 
Mittel-Meeres. Konigliche Preussische Akademie der Wissenschaften zu Berlin, Monatsberichte, Jahre 1858: 10-40.

Frizzell, D.L. \& Middour, E.S. 1951. Paleocene Radiolaria from southeastern Missouri. Bulletin University of Missouri School of Mines and Metallurgy, Technical Series, 77: 1-41.

Haeckel, E. 1862. Die Radiolarien (Rhizopoda Radiaria). Eine Monographie. Reimer, Berlin, xiv+572pp.

Haeckel, E. 1881. Entwurf eines Radiolarien-Systems auf Grund von Studien der Challenger-Radiolarien (Basis for a radiolarian classification from the study of Radiolaria of the Challenger collection). Jenaische Zeitschrift fur Naturwissenschaft, 15: 418-472.

Haeckel, E. 1887. Report on the Radiolaria collected by H.M.S. Challenger during the years 1873-1876. Report on the Scientific Results of the Voyage of the H.M.S. Challenger, Zoology, 18: clxxxviii+1803pp.

Hays, J.D. 1965. Radiolaria and late Tertiary and Quaternary history of Antarctic Seas. In: Llano, G.A. (Ed.), Biology of Antarctic Seas II. American Geophysical Union, Antarctic Research Series: 125-184.

Jørgensen, E. 1900. Protophyten und Protozoen im Plankton aus der norwegischen Westkuste. Bergens Museums Aarbog (1899), 2 (6): 1-112.

Kozlova, G.E. \& Gorbovetz, A.N. 1966. Radiolyarii verkhnemelovykh i verkhneeotsenovykh otlozhenii Zapadno-Sibirskoi nizmennosti (Radiolarians of the Upper Cretaceous and Upper Eocene deposits of the West Siberian Lowland). Trudy vsesoyuznogo neftyanogo nauchnoissledovatelskogo geologorazvedochnogo instituta (VNIGRI) [Proceedings of the All Union Petroleum Scientific Research Institute for Geological Survey (VNIGRI), 248: 1-159.

Lazarus, D. 1990. Middle Miocene to Recent radiolarians from the Weddell Sea, Antarctica, ODP Leg 113. In: Barker, P.F. \& Kennett, J.P. (Eds), Proceedings of the Ocean Drilling Program, Scientific Results, 113. Ocean Drilling Program, College Station, TX, 709-727.

Lazarus, D.B. 1992. Antarctic Neogene radiolarians from the Kerguelen Plateau, ODP Legs 119 and 120. In: Wise, S.W. \& Schlich, R. (Eds), Proceedings of the Ocean Drilling Program, Scientific Results, 120. Ocean Drilling Program, College Station, TX, 785-810.

Lazarus, D.B. 1998. The Ehrenberg Collection and its curation. In: Williams, D.M. \& Huxley, R. (Eds), Christian Gottfried Ehrenburg [sic] (1795-1876): The man and his legacy. The Linnean Society, London, 31-48.

Lazarus, D.B. \& Jahn, R. 1998. Using the Ehrenberg Collection. Diatom Research, 13 (2): 273-291.

Lazarus, D. \& Pallant, A. 1989. Oligocene and Neogene radiolarians from the Labrador Sea, ODP Leg 105. In: Srivastava, S.P., Arthur, M. \& Clement, B. (Eds), Proceedings of the Ocean Drilling Program, Scientific Results, 105. Ocean Drilling Program, College Station, TX, 349-380.

Moore, T.C. Jr 1973. Method of randomly distributing grains for microscopic examination. Journal of Sedimentary Petrology, 43 (3): 904-906.

Morley, J.J. 1985. Radiolarians from the Northwest Pacific, Deep Sea Drilling Project Leg 86. In: Heath, G.R. \& Burckle, L.H. (Eds), Initial
Reports of the Deep Sea Drilling Project, 86. US Government Printing Office, Washington, D.C, 399-422.

Nigrini, C. \& Lombari, G. 1984. A Guide to Miocene Radiolaria. Cushman Foundation for Foraminiferal Research, Special Publication, 22: i-Xvii, S1-S102, N1-N206.

Orsi, A.H., Whitworth, T. III \& Nowlin, W.D. Jr. 1995. On the meridional extent and fronts of the Antarctic Circumpolar Current. Deep Sea Research Part I: Oceanographic Research Papers, 42 (5): 641-673.

Petrushevskaya, M.G. 1967. Radiolyarii otryadov Spumellaria i Nassellaria antarkticheskoi oblasti [Antarctic Spumelline and Nasselline radiolarians]. Issledovaniya Fauny Morei, Resultaty Biologicheskikh Issledovanii Sovetskoi Antarkticheskoi Ekspeditsii 1955-1958 12, 4. Zoologicheskii Institut, Academiya Nauk SSSR, $1-186$.

Petrushevskaya, M.G. 1975. Cenozoic radiolarians of the Antarctic, Leg 29, DSDP. In: Kennett, J.P. \& Houtz, R.E. (Eds), Initial Reports of the Deep Sea Drilling Project, 29. US Government Printing Office, Washington, D.C, 541-675.

Popofsky, A. 1908. Die Radiolarien der Antarktis (mit Ausnahme der Tripyleen). In: Drygalski, E. (Ed.), Deutsche Sudpolar-Expedition, 1901-1903. Georg Reimer, Berlin, 183-306.

Riedel, W.R. 1958. Radiolaria in Antarctic sediments. Reports of the B.A.N.Z. Antarctic Research Expedition, series B: 217-255.

Riedel, W.R. 1967. Subclass Radiolaria. In: Harland, W.B. (Ed.), The Fossil Record. A symposium with documentation. Geological Society, London, 291-298.

Riedel, W.R. 1971. Systematic classification of polycystine Radiolaria. In: Funnell, B.M. \& Riedel, W.R. (Eds), The Micropalaeontology of Oceans. Cambridge University Press, Cambridge, 649-661.

Stöhr, E. 1880. Die Radiolarienfauna der Tripoli von Grotte (Provinz. Girgenti in Sizilien). Paleontographica, 26(3,2): 69-124.

Tan, S.H. 1927. Over de samenstelling en het onstaan van krijt- en mergel-gesteenten van de Molukken. Jaarboek van het mijnwezen in Nederlandsch Oost-Indie, verhandelingen, 3rd gedeelte, 55(1926): 5-165.

Weaver, F.M. 1976. Antarctic Radiolaria from the southeast Pacific basin, Deep Sea Drilling Project, Leg 35. In: Hollister, C.D. \& Craddock, C. (Eds), Initial Reports of the Deep Sea Drilling Project, 35. US Government Printing Office, Washington, D.C, 569-603.

Weaver, F.M. 1983. Cenozoic radiolarians from the Southwest Atlantic, Falkland Plateau region, Deep Sea Drilling Project, Leg 71. In: Ludwig, W.J. \& Krasheninnikov, V.A. (Eds), Initial Reports of the Deep Sea Drilling Project, 71. US Government Printing Office, Washington, D.C, 667-686.

Westberg-Smith, M.J. \& Riedel, W.R. 1985. Radiolarians from the western margin of the Rockall Plateau: Deep Sea Drilling Project Leg 81. In: Roberts, D.G. \& Schnitker, D. (Eds), Initial Reports of the Deep Sea Drilling Project, 81. US Government Printing Office, Washington, D.C, 479-501. 